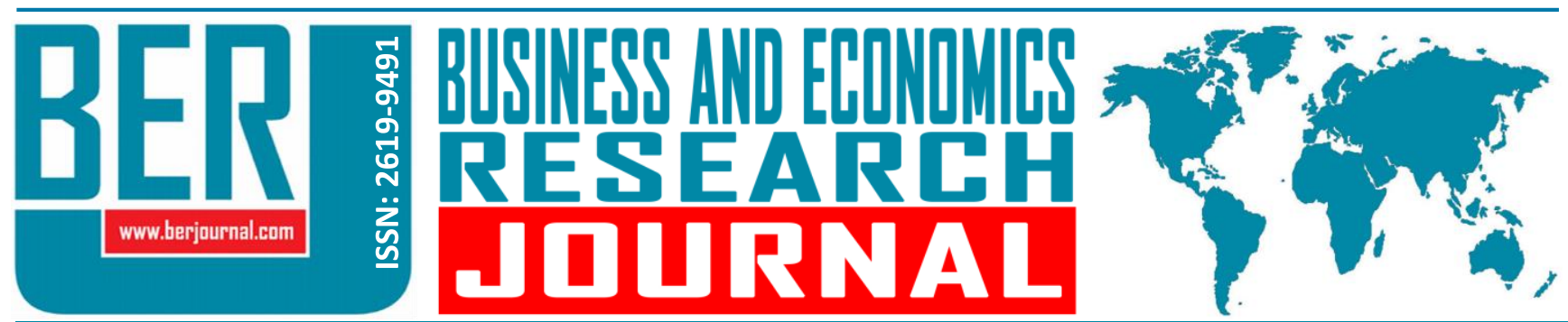

Business and Economics Research Journal Vol. 11, No. 3, 2020, pp. 647-669 doi: 10.20409/berj.2020.275

\title{
Yeni Kamu İşletmeciliği Bağlamında Kalkınma Planlarının Değerlendirilmesi: ARDL Sınır Testi Yaklaşımı
}

\author{
Eren Caskurlu ${ }^{\mathrm{a}}$, Erman Eroglu $^{\mathrm{b}}$
}

Öz: Geleneksel kamu yönetimi, refah devletinin egemen olduğu dönemde ağırlıklı olarak uygulanmıştır. Bu yaklaşımın temelinde kamu yararı ve bürokrasi yer almaktadır. Yeni kamu işletmeciliği yaklaşımı ise neoliberal düşünce çerçevesinde şekillenen ve devleti sınırlayan bir düşünce sistematiğidir. Bu kapsamda kamu harcamalarının ve kamu istihdamının azaltılmasına yönelik, özelleştirmelerin ağırlık kazandığı, deregülasyon ve kamu hizmetlerinin sunulmasında etkinlik artışını sağlayacak politikalar uygulanmıştır. Bu çalışmada yeni kamu işletmeciliği yaklaşımından hareketle Onuncu ve On Birinci Kalkınma Planlarında yer alan temel politikalar incelenmektedir. Planlarda kamu işletmeciliği ile ilgili dikkat çeken hususlar özelleștirmeye verilen önem, hesap verebilirlik ve mali yerelleșme olarak sıralanabilmektedir. Yapılan değerlendirmeler sonucunda iki planda da kamu işletmeciliği özelinde konulan hedeflerin ve öngörülen politikaların yeni kamu işletmeciliği yaklaşımına vurgu yaptığı belirtilebilmektedir. Çalışmanın ampirik uygulama kısmında kamu iktisadi teşebbüslerinde yaratılan katma değerin, tarım ve sanayi sektörü büyüme hızlarına etkisi araştırılmıştır. Bu kapsamda 1985-2017 dönem aralığında söz konusu değişkenler arasında ARDL sınır testi ile eşbütünleşme ve Toda - Yamomoto testi ile nedensellik incelenmiştir. Çalışma sonucuna göre kamu iktisadi teşebbüsleri katma değerinin tarım sektörü ve sanayi sektörü büyüme hızını artırdığı ve değişkenler arasında uzun dönemli pozitif ilişkinin varlı̆ı tespit edilmiştir.

\section{Evaluation of Development Plans within the Framework of New Public Management: ARDL Bound Testing Approach}

\begin{abstract}
Traditional public administration was mainly applied in the period when the welfare state was dominant. The new public management approach is a conception systematic shaped within the framework of neoliberal thought and limiting the state. Policies were implemented to reduce public expenditures and public employment, with privatization coming into prominence, and to increase efficiency in deregulation and provision of public services. In this study, the basic policies in the Tenth and Eleventh Development Plans are evaluated based on the new public management approach. The points that draw attention to public administration in the plans can be listed as the importance given to privatization, accountability, and financial localization. It can be pointed out that the goals and the policies envisaged in public management in both plans emphasize the new public management approach. In the empirical analysis part of the study, the effect of the added value created in the stateowned enterprises on the growth rates of the agriculture and industry sectors is investigated. In this context, cointegration with ARDL bound test and causality with Toda - Yamomoto between these variables in the period of 1985-2017 were examined. According to the results, the added value of stateowned enterprises increased the growth rate of the agricultural and industrial sectors and the presence of a long-term positive relationship between the variables was determined.
\end{abstract}

\section{Anahtar Sözcükler:}

Geleneksel Kamu Yönetimi, Yeni Kamu İşletmeciliği, Kalkınma Planları, Eşbütünleşme Analizi, Nedensellik Testi

JEL: H19, H89, O20

$\begin{array}{ll}\text { Geliş } & : 26 \text { Mart } 2020 \\ \text { Düzeltme } & : 03 \text { Haziran } 2020 \\ \text { Kabul } & : \text { 19 Haziran } 2020 \\ \text { Tür } & : \text { Araştırma }\end{array}$

Keywords: Traditional Public Administration, New Public Management, Development Plans, Cointegration Analysis, Causality Test

JEL: H19, H89, O20

$\begin{array}{ll}\text { Received } & : 26 \text { March } 2020 \\ \text { Revised } & : 03 \text { June } 2020 \\ \text { Accepted } & : \text { : } 19 \text { June } 2020\end{array}$

Type : Research

a Assoc. Prof., PhD., Ankara Hacı Bayram Veli University, Faculty of Economics and Administrative Sciences, Public Finance Department, Ankara, Turkiye, erencas@gmail.com (ORCID ID: 0000-0003-1447-6221)

b Res. Ass., Erciyes University, Faculty of Economics and Administrative Sciences, Public Finance Department, Kayseri, Turkiye, ermaneroglu@erciyes.edu.tr (ORCID ID: 0000-0001-6058-3592) 


\section{Giriş}

Ülkelerin karşılaşmış olduğu ekonomik krizler ile birlikte zaman içerisinde ideolojik yapılar da değişim göstermiştir. Buna bağlı olarak devlete biçilen rol de sürekli farklılaşmıştır. Kamu yönetimine yönelik yaklaşımların da bu çerçevede değişim geçirdiği görülmektedir. Sosyal refah devleti bünyesinde geleneksel kamu yönetimi yaklaşımı ağırlıklı olarak uygulanırken, benimsenen temel ilke kamu yararının sağlanması olmuştur. Neoliberal düşüncenin ağırlık kazanmasıyla birlikte yeni kamu işletmeciliği yaklaşımı gündeme gelmeye başlamıştır. Yeni kamu işletmeciliğine yönelik temel kavramlar ise esneklik, rekabetçiliğin sağlanması, hesap verebilirlik, yönetişim ve özelleştirmeler olarak sıralanabilmektedir. Dolayısıyla gelişmekte olan ülkelerde geleneksel kamu yönetiminden, yeni kamu işletmeciliğine doğru bir yönelim gözlenmiştir. Çalışmanın teorik boyutunu bu doğrultuda geleneksel kamu yönetimi ve yeni kamu işletmeciliği yaklaşımları oluşturmaktadır.

Çalışmanın temel amacı yeni kamu işletmeciliği yaklaşımından hareketle Onuncu ve On Birinci Kalkınma Planlarının değerlendirilmesi ve yapılan ampirik çalışma sonuçlarının kalkınma planları ile uyumlu olup olmadığının incelenmesidir. Bu nedenle Türkiye'deki süreci gözlemleyebilmek adına kalkınma planları değerlendirilmektedir. Bu kapsamda ilk olarak geleneksel kamu yönetimi yaklaşımından yeni kamu işletmeciliği yaklaşımına gelen süreç ve yaklaşımların özellikleri değerlendirilmektedir. Devamında ise gelişmekte olan ülkelerde ve Türkiye'de kamu işletmeciliğinin geçirdiği süreç anlatılmaktadır. Onuncu ve On Birinci Kalkınma Planları bu çerçevede incelenmektedir. Son bölümde ise kamu iktisadi teşebbüsleri tarafından yaratılan katma değerin, tarım ve sanayi büyüme hızlarına etkisi ampirik olarak analiz edilmektedir. Çalışma ele alınan kavramların teorik, uygulama ve değerlendirme boyutlarını kapsamaktadır. Literatürde kamu iktisadi teşebbüslerinin sektörel etkinliğini inceleyen ve kalkınma planlarındaki süreçle bağdaştıran bir çalışma olmadığı için bu boşluğun doldurulacağı düşünülmektedir.

\section{Geleneksel Kamu Yönetiminden Yeni Kamu İşletmeciliğine}

\subsection{Geleneksel Kamu Yönetimi Yaklaşımı}

Klasik yaklaşım olarak da bilinen, geleneksel kamu yönetimi yaklaşımı 19. yüzyılın sonlarında ortaya çıkmış ve II. Dünya Savaşı'ndan sonra refah devleti anlayışı ile zirveye ulaşmıştır. Devletin sosyal ve ekonomik hayatta etkili olması geleneksel yaklaşımda ön plana çıkan özelliklerden biridir (Kaya, 2017). Refah devleti anlayışı döneminde devlet sadece ekonomik süreçleri düzenlemekle kalmamış sürecin bir parçası da olmuştur. Başka bir deyişle, refah devletinin oluşması ve kurumsallaşması devlet eliyle gerçekleştirilmiştir (Güzelsarı, 2004). 1920-1970 döneminde altın çağını yaşayan geleneksel kamu yönetimi, sert ve bürokratikti; yönetim ve siyasetin ayrı olması gerektiği nosyonu, istikrarlı dönemlerde uygulanabilir bir model olarak kullanılmıştır (Hughes, 2014). Geleneksel kamu yönetimi yaklaşımı Woodrow Wilson'un “idarenin ve siyasetin ayrılması", Frederick Taylor'un "bilimsel yönetimi" ve Max Weber'in "hiyerarşik kontrolü" bağlamında kendisini kabul ettiren bir yaklaşımdır ve bu görüşler temelinde şekillenmiştir (Leblebici, 2001; Yıldırım, 2009).

Geleneksel kamu yönetimi, yöneticinin dikkatini çeken amaç ve değere yönelik sorularına veya meşruiyet ve desteğin geliştirilmesine odaklanmamaktadır. Bu yaklaşım, bu soruların yasama ya da politika yapımı sırasında yöneticiler tarafından yanıtlandığını, hedeflere olabildiğince verimli bir şekilde ulaşmak için mevcut kaynakları etkin bir şekilde kullanma görevini yerine getirmeleri gerektiğini varsaymaktadır. Bu hedefi gerçekleştirirken, yöneticiler örgütsel tasarım, bütçeleme, insan kaynakları gelişimi ve kontrolü gibi yönetim araçlarına güvenmektedirler (Lynn Jr., 2001).

Geleneksel kamu yönetimi, temel olarak bürokratik paradigma üzerine şekillenmiştir. Kamu yararı, verimlilik, tanımlanmış görev ve otorite yapısı, hiyerarşi, idari sorumluluk ve kontrol geleneksel kamu yönetimi yaklaşımı açısından önem taşıyan kavramlardır (Genç, 2010). Bu bağlamda bürokrasi ise, hükümetin otorite üzerine kurulduğu daha geniş bir örgütsel ve normatif yapıyı; yani meşru, rasyonel-yasal bir siyasal düzene olan inanç ve devletin yasal düzeni tanımlama ve uygulama hakkını ifade etmektedir. Geleneksel kamu yönetimi yaklaşımı, örgütsel özellikler ile idari zihniyet, davranış, performans ve değişim arasındaki ilişkilere yönelik teorik fikir ve hipotezleri ele almaktadır (Olsen, 2006). Bu yaklaşım, kamu sektöründe, en 
uzun süre varlığını koruyan ve en başarılı olarak nitelendirilen yönetim teorisi olarak yer almaktadır (Hughes, 2014).Geleneksel kamu yönetimi yaklaşımının temel ilkelerinden birisi kamu yararıdır. Ayrıca kamu yönetiminde piyasaya dayalı ölçütlerden ziyade kurallara bağlıık esastır. Geleneksel kamu yönetiminin diğer ilkelerinden bazıları şu şekilde sıralanabilir (Kaya, 2017): Hesap verebilirlik mekanizması siyasilere karşıdır. Kamu hizmetleri, geleneksel devlet kurumları vasıtasıyla topluma sunulmaktadır. Bürokratik yapı bünyesinde kuralcılık son derece önemlidir. Kamu hizmetinin sunumunda kamu yararı sağlamak temel esaslardan biridir. $\mathrm{Bu}$ ilkeler çerçevesinde uzunca bir süre birçok ülkede geleneksel kamu yönetimi anlayışı varlı̆ı̆nı sürdürmüştür. Ancak zaman içerisinde çeşitli siyasi, ekonomik ve ideolojik nedenlere bağlı olarak önemi azalmıştır.

1970'li yıllarda geleneksel kamu yönetimi açısından sorun olarak görülmeye başlanan temel unsurları şunlardır: Yönetimin daha karmaşık hale gelmesi ve zor bir hal almış olması, kurumların aşırı büyük yapıları ve hizmet yelpazesindeki genişleme, süreçlerin yasalığının ön plana çıkarılması ve sonuçların göz ardı edilmesi, esnek olmayan kurumsal yapılar, mali kaynak kıtlığı ile birlikte kaynakların verimli kullanılamamasıdır (Tuncer ve Usta, 2013). Bütün bunların sonucunda da ülkelerde geleneksel kamu yönetimi değerlerinden uzaklaşma görülmüş ve yerine daha farklı uygulamalar tercih edilmeye başlamıştır.

\subsection{Yeni Kamu İşletmeciliği Yaklaşımı ve Gelişimi}

1970'li yıllarda yaşanan iki petrol krizi, kamu bütçelerinin artan açıklarıyla birlikte bu sorunlara çözüm olabilmesi için yeni kamu işletmeciliği yaklaşımı ortaya atılmıştır. Devletin büyümesinin önüne geçmek, kamu hizmetlerinde özelleştirme ve yerelleşmeye yönelim, bilgi teknolojilerinde, kamu hizmetlerinin üretiminde ve dağııımında otomasyonun gelişimi (Kurun, 2017: 87) bu yaklaşımın gündeme gelmesinin altında yatan etmenler olarak ifade edilebilir. Bu bağlamda sınırlı bir devletin yanında ekonomik, etkin ve etkili kamu hizmet sunumu sağlayabilecek yeni yönetsel yapı arayışı söz konusu olmuştur (Karcı, 2008). 1980'li yıllarda zirveye ulaşan bu yaklaşım, geleneksel kamu yönetimine meydan okumuştur (Ayhan ve Önder, 2017). Yeni kamu işletmeciliği, kamu sektörü ve özel sektör, uzmanlar ve yöneticiler, merkez ve yerel yönetim arasındaki ilişkileri yeniden düzenleyen ve açıklayan bir dizi reformu tanımlamak üzere kullanılmaktadır (Newman, 2000). Başka bir ifadeyle, yeni kamu işletmeciliği ile özel sektörde uygulanan yönetim tekniklerinin kamu sektörü bünyesinde yer alması ifade edilmektedir.

$\mathrm{Bu}$ yaklaşım temel olarak neoliberal düşünce çerçevesinde şekillenmiş ve devleti sınırlayan ve özelleştirme ile birlikte farklı hizmet sunum yöntemleri geliştiren bir düşünce sistematiğidir. Bu çerçevede; kamu harcamalarının ve kamu istihdamının azaltılması, deregülasyon ve kamu hizmetlerinin sunulmasında etkinlik artışını sağlayacak politikalar uygulanmıştır (Karcı, 2008). Bu yaklaşımla birlikte devlete artık farklı perspektiften bakılmakta ve kamu yönetiminin de özel sektör kurallarına bağlı olarak, performansa dayalı yönetilmesi gerektiği savunulmaktadır.

Yeni kamu işletmeciliği yaklaşımındaki temel özellikler şu şekilde sıralanabilmektedir (Araujo ve Branco, 2009): Sonuçların ilgi odağı olması, esnek yönetim kuruluşları ve esnek istihdam şartlarının sağlanması, açık bir şekilde tanımlanmış hedefler ve performans göstergelerinin varlığı, kamu hizmetlerini yerine getirilebilmek için piyasaların kullanımı ve özelleştirme aracılığıyla devlet fonksiyonlarının azaltılmasıdır.

Yeni kamu işletmeciliğinin, isimlendirilmesinde yönetim yerine işletme kelimesinin kullanılması dikkat çekici bir ayrıntıdır. Kamu yönetimindeki sorunlar kabul edilmekte ve özel sektörün işletmecilik teknikleri ile bu sorunların çözüleceği anlatılmaya çalışıımaktadır. Bu doğrultuda hiyerarşinin ağılıkta olduğu yapı yerine daha katılımcı, esnek ve geçici yapılar gündeme gelmiştir. Devletin piyasa mekanizmaları ile tanışması yolundaki adımlar; yetki devri, kamu-özel ortaklıkları, sözleşme yoluyla hizmet satın alımı olarak belirtilebilmektedir (Tuncer ve Usta, 2013). Kamu hizmetlerinin sunulmasında kurala dayalı bir yönetim tarzından amacın önem taşıdığı bir yönetim tarzına geçme düşüncesi, yeni kamu işletmeciliğinin temel özelliklerinden biridir. Kamu kuruluşlarının ve kamu hizmetlerinin performanslarının 3E (ekonomiklik, etkinlik, etkililik) analizi ile ölçülmesi gerekliliğine önem verilmektedir (Karcı, 2008). Işıkçı (2017)'ya göre "yeni kamu işletmeciliği, kamu yönetimi disiplini içinde neoliberal düşüncenin "minimal devlet" anlayışının kamu 
yönetimi alanına uyarlanmış hali" olarak tanımlanmaktadır. Bu nedenle doğal dengenin sağlanması ile birlikte en verimli kaynak kullanımının mümkün olacağı savunulmaktadır (Şener, 2007).

\subsection{Yeni Kamu İşletmeciliğinin Kuramsal Altyapısı}

\subsection{1. İşletmecilik}

Yeni kamu işletmeciliği sadece işletmecilik tekniklerinin değil değerlerinin de kamu yönetimine; hesap verebilirlik, toplam kalite ve performans yönetimi ile şeffafık gibi araçlarla aktarılmasının kuramsal temelini sağlayan yeni bir yöntem olarak kabul edilmektedir (Akbulut, 2007). Bu anlayış bürokraside işletmecilik ilkelerinin uygulanmasının gerekliliğine dikkat çekmektedir (Sobacı, 2006). İşletmecilik (managerialism), bürokraside işletme yönetimi ilkelerinin egemen kılınması düşüncesine dayanmaktadır. Bu ilkeye göre, kamu kurum ve kuruluşlarının yöneticileri kural uygulamak yerine başlarında oldukları örgütleri yönetmek ve değiştirmek için sorumluluk almaktadır. Yöneticilerin sonuç odaklı olmaları sonucunda kamu kurum ve kuruluşları kamu hizmetlerini daha etkin sunmaktadır (Karcı, 2008). Bu bağlamda yöneticilere sorumluluk verilmesi, hesap verebilirliği de oluşturmaktadır.

İşletmecilik anlayışı çeşitli ilkelere dayanmaktadır. Bu ilkeler; ekonomik olarak tanımlanmış verimlilik doğrultusunda bir sosyal gelişme, verimliliği arttırmak için gelişmiş teknolojilerin kullanılması, verimlilik ideali doğrultusunda motive olmuş bir iş gücü, daha fazla verimliliği sağlamada anahtar rol oynayan yönetici ve yönetsel esneklik ya da yönetme hakkıdır (Pollitt, 1990). Kamu işletmeciliği yaklaşımı hem işletmecilik tekniklerinin kamu yönetiminde verimlilik ve etkinlik hedeflerine ulaşılabilmesi için kullanılmasını hem de kamu hizmetlerinin özel sektör amaç ve hedeflerine göre biçimlenebileceğini savunmaktadır. Bu yaklaşım, açıkça tanımlanmış standart ve performans ölçütlerini, sonuç odaklılığı, profesyonel yönetim tekniklerini ve hesap verme yükümlülüğünü öne çıkarmaktadır (ışıķ̧ı, 2017). Kamu mali yönetimi açısından bakıldığında, devlet bütçe sistemlerinin süreç içerisinde geçirdiği değişim işletmeciliğin bir yansımasıdır. Nitekim özel sektör esaslı bütçeleme sistemleri zaman içerisinde devlet bütçelerine uygulanmıştır. Performans, stratejik plan, raporlama ve hesap verebilirlik kavramlarının bütçe sistemlerinde yer alıyor olması bu duruma kanıt niteliğindedir.

\subsubsection{Kamu Tercihi Teorisi}

Kamu tercihi teorisinin temelleri 18.yy’a kadar uzandığı belirtilmekle birlikte, gelişimi II. Dünya Savaşı sonrasında kamu kesiminin hızlı büyümesi karşısında gerçekleşmiştir (Dura, 2006). Kamu tercihi, refah devleti döneminde genişleyen bütçenin sermayenin karlılığı üzerindeki olumsuz etkisini ortadan kaldırmaya yönelik bir teoridir. Dolayısıyla bütçe sürecini dönüştürmeye ve bürokrasiyi yeniden yapılandırmaya odaklanmaktadır (Akbulut, 2007). Kamu tercihi "refah devletinin başarısızlığı" temelinden hareket etmektedir.

Kamu tercihi teorisi esas olarak üç temel varsayıma dayanmaktadır. Bunlar sırasıyla, metodolojik bireyselcilik, maximand ilkesi ve politik mübadele ilkesidir. Siyasal karar alma sürecinde yer alan aktörlerin (seçmenler, siyasi partiler, politikacılar, bürokratlar, çıkar grupları) rasyonel oldukları ve özel çıkarlarını maksimize etme eğiliminde oldukları kabul edilir (Aktan ve Bahçe, 2013). Bu teori, geleneksel kamu yönetimi yaklaşımına keskin bir şekilde karşı olan fikirler sunmuştur. Örneğin, bireysel olarak bürokratların ve siyasetçilerin sadece kamusal çıkar ile donanmış olduklarını düşünmek yerine, kendi faydalarını maksimize etmeye ve kendi refahlarını artırmaya çalışan insanlar olarak görmek gerektiğini savunmaktadır. Kamu tercihi teorisyenleri genellikle en iyi çıktının piyasaya maksimum düzeyde rol vererek ve hükümetin rolünü de minimal hale getirerek elde edileceği sonucuna ulaşmaktadırlar (Hughes, 2014). Kamu tercihi teorisi ile kamu kurumları arasındaki rekabeti teşvik etmenin ve bürokratların genişlemeci eğilimlerini kontrol altında tutmanın en iyi yolunun, piyasa güçlerini ve hesap verebilirlik mekanizmalarını önemsemekte olduğu ifade edilmektedir (Yıldırım, 2011).

Bu teori ile kamudaki yöneticilerin, kamu yararını gözeterek değil, aksine kendi kişisel çıkarları doğrultusunda davrandıkları iddia edilmektedir. Böyle bir durumda kamu yönetimi ve kamu ekonomisinin verimli bir şekilde işlemesi mümkün değildir. Bu nedenle de, kamusal hizmetlerin sunumunda devlete daha az rol verilmeli ve temel aktör piyasa güçleri olmalıdır (Işıkçı, 2017). Kamu tercihi teorisine göre devletin 
başarısız olarak düşünüldüğü için piyasalar oluşturulmalı ve bunlara işlevsellik kazandırılmalıdır. Devlet, toplumdaki aktörler nedeniyle sürekli büyüme eğilimindeki bir yapıdır ve mümkün olduğunca sınırlanması savunulmaktadır. İşte bu noktada kamu tercihi teorisinin, yeni kamu işletmeciliğine temel oluşturduğu belirtilebilir.

Kamu tercihi ile ekonomi bilimi çerçevesinde geliştirilmiş araç ve metotların siyasal karar alma sürecine uygulanması söz konusudur. Bu nedenle alınan her türlü kararın iktisadi araçlar yoluyla analizi yapılmaktadır. Kamudaki politik, bürokratik-idari süreçlerin ise iktisadi olarak etkinsiz ve verimsiz olduğu, bu süreçlerin işleyişi ortaya konularak açıklanmaya çalışılmaktadır (Dura, 2006). Bütün bu nedenler yeni kamu işletmeciliğinin, benimsenip uygulanabilmesi için bir altyapı oluşturmuştur.

\section{Gelişmekte Olan Ülkelerde Kamu İşletmeciliği}

\subsection{Gelişmekte Olan Ülkelerde Geleneksel Kamu Yönetimi ve Yeni Kamu İ̧̧letmeciliği}

Geleneksel kamu yönetimi anlayışı, bağımsızlığını kazanan gelişmekte olan ülkelerde ilk olarak uygulanan kamu idaresi yöntemidir. Bu ülkelerde yönetime bürokratik bir yaklaşımla bakılarak, ekonomide kamu sektörünün ağırlıkta olduğu güçlü bir yapı benimsenmiştir. Ekonomik büyümenin en hızlı yolunun işletmelerin devlete ait olması ve özel sektöre müdahale ile gerçekleşeceği düşünülmüştür (Hughes, 2014). Bu düşüncenin savunulmasında, gelişmekte olan ülkelerde özel sektörün sermaye yetersizliği, tasarruf oranlarındaki düşüklük ve toplumsal yapının etkisi söz konusudur.

Gelişmekte olan ülkelerin sosyo-kültürel yapısı ve dinamikleri gelişmişülkelere göre daha farklıdır. Yöneticiler bu ülkelerde genellikle otoriter, paternalist yapıya ve kolektivist kültüre sahiptirler. Bu nedenle gelişmekte olan ülkeler için geleneksel kamu yönetimi yaklaşımı daha uygun görülmüştür. Ancak bu model bile, birçok gelişmekte olan ülke için çok uzak görünmektedir. Gelişmekte olan ülkelerin çoğunda, kamu kurumlarında siyasallaşma geleneksel kamu hizmeti değerlerinin aşınmasına neden olmuştur. Bireysel liyakat ve eşitliğe dayanan Weberyen bürokrasinin birçok gelişmekte olan ülkede uygulanamadığı görülmektedir (Soeters ve Tessema, 2004). Kamu yönetiminin kalkınma için kullanımı II. Dünya Savaşı́ndan sonraki dönemde gelişim göstermiştir. Bu düşüncenin altında yatan husus Batı'nın izledikleri tekniklerin gelişmekte olan ülkelere uygulanmasıydı (Hughes, 2014). Böylelikle gelişmekte olan ülke ekonomileri modernize olacak ve gelişmiş ülkelerle arasındaki fark kapanacaktı.

Yeni kamu işletmeciliği yaklaşımının, gelişmekte olan ülkelerde yolsuzluk ve düşük idari kapasite gibi sorunlar nedeniyle uygun olmadığı savunulsa da, başarısızlıkla sonuçlananlar olduğu gibi başarı hikayelerinin de olduğu görülmektedir (Polidano, 1999). Burada önemli olan husus ülke özelinde hangi unsurların faydalı olup, hangilerinin faydalı olmayacağına ihtiyaçlar doğrultusunda karar verilmesidir. Geleneksel kamu yönetiminin etkin uygulanabileceği alanlar olduğu gibi, yeni kamu işletmeciliği açısından bazı hususların sistem içerisinde eşanlı olarak yer alabilmesi de mümkündür.

Gelişmekte olan ülkeler, kamu teşekküllerinden çoğu gelişmiş ülkeye göre daha fazla fayda elde etmektedir. Bu durumun nedenlerinden biri sermaye piyasasından kaynaklanan sorunlardır. Bu ülkelerde sermaye piyasası gelişmemiş ve özel sektör güçsüz olduğu için kamu yatırımları önem arz etmektedir. Birtakım başarılara rağmen gelişmekte olan ülkelerde kamu teşebbüsleri; düşük karlılık, yatırım verimliliği ve stratejik sorunlar ile tanımlanmıştır. Zarar eden teşebbüsler devlet bütçesinde bir yük oluşturunca, 1980'li yıllarda devletin rolü sorgulanmaya başlamıştır. Siyasi tarafsızlık, yolsuzluk ve bürokrasinin belli bir elit gruba, dini veya etnik çıkarlar doğrultusunda kullanımı örnek olarak verilebilir. Başarısızlığın nedeni ise yönetişim başarısızlığı olarak ifade edilebilir (Hughes, 2014).

1990 'lı yıllarda ise daha pragmatist bir yöntem izlenmeye başlanmıştır. Bu yönteme göre minimal devletin yanında, piyasaların destekleneceği ve kalkınma için devletin rakip olmayacağı bir yapı inşa edilmelidir (Hughes, 2014). Stiglitz (1998)'e göre devlet ve piyasalar birbirinin tamamlayıcısı olarak görülmelidir. Devlet ve özel sektör kendi sorumluluk alanlarında çalışan ortaklar olarak nitelendirilebilir. Diğer durumlarda devletin özel bir sorumluluğu vardır. Bu sorumluluk, piyasaların etkin bir şekilde çalışabilmesi için intiyaç duyduğu kurumsal altyapının sağlanması olarak açıklanabilir. 
Gelişmekte olan ülkelerin genelinde geleneksel kamu yönetiminden, yeni kamu işletmeciliğine doğru bir yönelim mevcuttur. Bu yönelimin gerçekleşmesinde uluslararası finansal kuruluşların gelişmekte olan ülkelere yazmış oldukları politika reçeteleri, küreselleşme ve gelişmiş ülkelerin izlediği yollardan geçerek kalkınmanın sağlanabileceğine olan inanç etkili olmaktadır. Her gelişmekte olan ülke için aynı modeli uygulamak doğru bir yaklaşım olarak değerlendirilemez. Bu aşamada üzerinde durulması gereken husus, ülkenin kendi iç dinamiklerine, idari ve ekonomik yapısına uygun olarak şekillendirme yoluna gidilmesidir. Dolayısıyla, sorun konjonktürel değil yapısal nedenlerden ileri gelmektedir. Tasarlanan sistemlerin hiçbiri kusursuz olmadığı gibi, sistemin uygulayıcıları çarkın işlemesine katkı sağlayacaktır.

\subsection{Türkiye'de Kamu İşletmeciliğinin Gelişimi ve Türleri}

Tarihsel süreçte devletin ekonomi içerisindeki konumu sürekli tartışma konusu olmuştur. Devlet müdahalesinin yoğunluğu ve müdahale biçimleri, ekonomik sosyal ve siyasi nedenlere göre farklı boyutlarda olsa da, devletin sürekli olarak ekonomik ve sosyal yaşamın içinde olduğu dikkat çekmektedir. Devletin idari yapılanması ile ekonomi içerisinde yer alması kamu işletmeciliğinin boyutunu göstermektedir. Türkiye'de de bu sürecin küresel konjonktürle benzer biçimde şekillendiği ifade edilebilmektedir.

Kamu İktisadi Teşebbüsü (КіT) kavramı ülkeden ülkeye değişmekle birlikte, genel olarak kamusal kaynakları kullanmak suretiyle ekonomik alanda faaliyet gösteren devlet kuruluşlarını ifade etmek üzere kullanılmaktadır (Kurt, 2018: 10). 233 sayılı Kamu İktisadi Teşebbüsleri Hakkında Kanun Hükmünde Kararname'de (KIT) kavramı, sermayesinin tamamı devlete ait olan iktisadi devlet teşekkülü ve kamu iktisadi kuruluşlarının ortak adı olarak kullanılmaktadır. iktisadi devlet teşekkülü, iktisadi alanda ticari esaslara göre kâr amacı güderek faaliyet gösteren teşebbüslerdir. Kamu iktisadi kuruluşu ise iktisadi alanda tekel niteliğini haiz mal ve hizmetleri kamu yararı gözeterek üreten ve pazarlayan teşebbüslerdir. Özellikle 1930 'lu yıllardan itibaren KiT'ler Türkiye ekonomisi bünyesinde önemli bir yere sahip olmuştur. Türkiye'de KiT'ler geniş perspektiften ve farklı yönlerden incelenebilecek bir kavramdır. Ancak çalışmanın bu bölümünde KiT'lere ilişkin dönemsel bakış açıları ve ekonomi içerisindeki konumu değerlendirilerek, Türkiye'de kamu işletmeciliğinde yaşanan değişim vurgulanmaya çalışılmaktadır.

Cumhuriyetin kurulduğu ilk yıllarda özel sektördeki sermaye, teknoloji ve bilgi birikimi yetersizliği nedeniyle, kamu yatırım ve girişimciliği ile bu eksiklik giderilmeye çalışılmıştır (Sarısu, 2008). Türkiye'de kamu işletmeciliği açısından, özellikle 1930 'lu yıllarda devletçilik anlayışı ile birlikte, devletin ekonomik hayatta yer alması kamu girişimciliği şeklinde gerçekleşmiş̧ir. 1930'lu yıllardan günümüze kadar olan süreçte devlet bünyesinde yer alan kurum ve kuruluşlar şu şekilde sıralanmaktadır (Çetinkaya, 2012): Döner sermayeli işletmeler, Kiт’ler, iktisadi kamu kurumları (özel bütçeli idareler), diğer kamu işletmeleridir. Bu kurum ve kuruluşlar, ekonomik nitelikte faaliyette bulunan, mal ve hizmet üretip sunan veya satan kuruluşlardır. 19301950 yıllarını kapsayan dönemde yirmi bir KiT ekonomi bünyesine dahil olduğu ve Kiт’lerin bu dönemde özellikle sanayi planlarıyla birlikte iktisadi gelişmenin tam merkezinde yer aldığı için KiT'lerin "kuruluş dönemi" olarak değerlendirilmektedir (Övgün, 2009). Dolayısıyla söz konusu dönemde kamu yararı doğrultusunda, kamu girişimciliğinin ön planda tutulduğu belirtilebilir. Bu durumun, hem devletçilik anlayışının benimsenmesi hem de koşulların devleti bu girişimleri yapmaya zorunlu kılması nedeniyle oluştuğu ifade edilebilmektedir.

II. Dünya Savaşı sonrasında devletçilikten uzaklaşılması öngörülmesine rağmen bu uygulanamamış, tam tersi yeni KiT’ler kurulurken özel bütçeli kurumlar Kiт haline getirilmiştir (Çetinkaya, 2012). 1950-1980 yıllarını kapsayan dönemde yirmi yedi yeni KiT'in daha kurulmuş olması KiT'ler için "gelişme dönemi" olarak nitelendirilmesine yol açmaktadır. Dönem özelinde bir ayrım yapılacak olursa 1950-1960 yılları arasında, KiT'ler özel sektörü destekleyici bir konuma getirilmiştir. 1960-1980 yılları arasında ise kalkınma planları çerçevesinde KiT’ler ekonomik gelişmeyi ve özel sektörü destekleyici güç olarak görülmüştür. 1950-1960 yılları arasındaki dönemde Kiт’lerin sayısındaki artışın gerekçesi, üretimi temel tüketim mallarından yatırım mallarına yöneltmek olarak açıklanabilir. Ayrıca bu dönemde Kiт’lerin istihdam sağlama özelliğinden faydalanılmıştır (Övgün, 2009). 1960'lı yıllarda KiT'ler ithal ikameci sanayileşme politikasına yönelik olarak sermaye yoğun ara girdi üreten sanayilerin kurulmasında etkili olmuştur (Kurt, 2018). 
1980 yılına gelindiğinde ise 24 Ocak 1980 kararları ile birlikte serbest piyasa ekonomisinin benimsenmesi ile kamu işletmeciliği anlayışında da değişikliklere gidilmesi hususu gündeme gelmiştir (Çetinkaya, 2012). 1980'li yıllara kadar Türkiye'de devletin geleneksel özelliklerinin devam etmesi sonucunda, ekonomi kamu ihtiyaçları doğrultusunda şekillenmiştir (Sarısu, 2008). 1980'li yıllarda ise, devletin varlığı ve etkisi ekonomide azaltılmaya çalışıımış, 1990'lı yıllarda özelleştirme uygulamaları biraz hızlanmış ve buna bağlı olarak KiT'lerin piyasadaki sahip olduğu konum ve önem azalmaya başlamıştır (Kurt, 2018). Bu sonuca ulaşılmasında temel etken, serbest piyasa ekonomisi kural ve uygulamalarının ekonomi bünyesinde ağılıkı olarak yer almaya başlamasıdır. Genel olarak literatürde (Çetinkaya, 2012) 1980'li yılların ikinci yarısı ile 1990 'I yıllar özelleştirme uygulamalarına yasal zeminin hazırlandığı dönem veya "KiT’lerin çözülme dönemi" (Övgün, 2009) olarak ifade edilmektedir.

2000 'li yıllara gelindiğinde dünya genelinde Dünyada özelleştirme uygulamalarının hız kesmeden devam ettiği gibi Türkiye'deki özelleştirmeler de aynı doğrultuda devam etmiştir (Güler, 2019). Kiт’lerin bu dönemdeki temel amacı verimlilik ve kârlılık olarak nitelendirildiği ve bu açıdan başarısız olarak değerlendirildiği için söz konusu dönemde özelleştirme uygulamalarının hız kazandığı görülmektedir (Övgün, 2009). Türkiye'de devletçilik, piyasa ekonomisi ve planlı ekonomi uygulamaya yönelik tercihler ideolojik değil; tamamen zorunluluklara dayanmaktadır. Bu anlamda, hem planlı ekonomi hem de piyasa ekonomisi tercihi tartışmaları cumhuriyetin ilk yıllarına kadar gittiği görülebilir (Güler, 2019). Dolayısıyla uygulanan ekonomi politikalarının, tarihsel süreç içerisinde kamu işletmeciliği açısından tutumu şekillendirildiği görülmektedir.

\section{Onuncu ve On Birinci Kalkınma Planlarının Yeni Kamu İşletmeciliği Temelinde Değerlendirilmesi}

Çalışmanın bu başlığa kadar olan kısmında geleneksel kamu yönetimi ve yeni kamu işletmeciliği ele alınarak gelişmekte olan ülkelerdeki süreç değerlendirilmiştir. Bu başlıkta kalkınma planları ile yeni kamu işletmeciliği anlayışı kuramsal ve uygulamadaki değişimin yansıtılabilmesi adına ele alınmaktadır.

\subsection{Onuncu Kalkınma Planında Kamu İşletmeciliği}

Onuncu Kalkınma Planı (OKP)'nın hedef ve politikaları başlığında "nitelikli insan, güçlü toplum" için karar alma ve uygulama süreçlerinde esnek, katılımcı, şeffaf ve yeterli kurumsal kapasiteye sahip bir kamu yönetimi ve güçlü bir sivil toplumun varlığının öncelikli (T.C. Kalkınma Bakanlığı, 2013: 29) olduğu belirtilmiştir. Özellikle esnek, katılımcı ve şeffaf bir kamu yönetiminin hedeflenmesi, yeni kamu işletmeciliğinin temel özelliklerine vurgu yapıldığını göstermektedir. OKP'de kamu işletmeciliği kapsamında durum analizinde yer alan ifadelerden yeni kamu işletmeciliği yaklaşımı ile örtüşen hususlar şöyle ifade edilebilir:

- KiT’ler hâlihazırda, madencilik, enerji, ulaştırma, tarım ve imalat sanayii sektörlerinde faaliyet göstermektedir. Dokuzuncu Kalkınma Planı döneminde kamu, petro-kimya, tuz ve tütün sektörleri ile araç muayene istasyonları işletmeciliğinden tamamen çekilmiştir. Elektrik dağıtımı ve üretimi, doğal gaz dağııımı, imalat sanayii, liman işletmeciliği, telekomünikasyon, bankacılık, denizyolu ve havayolu taşımacılığı alanlarında bir kısım özelleştirmeler gerçekleştirilmiştir (T.C. Kalkınma Bakanlığı, 2013). Buna göre, devletin tamamen elini çektiği sektörler olması ve özelleştirmelerin birçok sektörde devam ediyor olması yeni kamu işletmeciliği yaklaşımının unsurlarından özelleştirmenin benimsendiğini göstermektedir.

- Dokuzuncu Kalkınma Planı döneminde, özelleştirme kapsamında olmayan kamu işletmelerinde stratejik yönetim anlayışının yerleştirilmesi ve yaygınlaştırılması amacıyla stratejik planların hazırlanması ve uygulanması süreci başlatılmıştır. Modern iç kontrol ve iç denetim sistemlerinin hayata geçirilmesine yönelik adımlar atılmıştır. KiT'lerde fiyatların piyasa şartlarına uygun bir şekilde belirlenmesine ve atıl istihdamın azaltılmasına yönelik uygulamalar ile kurumsal yönetimin iyileştirilmesine yönelik çalışmalar sürdürülmüştür (T.C. Kalkınma Bakanlığı, 2013). Buradan hareketle özel sektör temelli stratejik yönetim, stratejik plan ve iç denetim sistemi kavramlarına kamu işletmelerinde uygulama alanı verilmesi yeni kamu işletmeciliğine işaret etmektedir. Ayrıca 
KiT’lerin "gelişme döneminde" sahip olduğu istihdam sağlama işlevinin büyük ölçüde azaldığı vurgulanabilir. sıralanabilir:

OKP'de yer alan yeni kamu işletmeciliği ve neoliberal politikalar temelindeki hedefler şu şekilde

- Kamu sermayeli işletmelerin kamuya yük getirmeden, verimlilik ilkesi çerçevesinde faaliyet göstermeleri temel amaçtır (T.C. Kalkınma Bakanlığı, 2013: 79). Geleneksel kamu yönetimi yaklaşımına göre kamu yararı temel amaç iken, bu madde ile verimliliğin temel amaç olduğu belirtilmektedir.

- Plan dönemi sonunda özelleştirme programındaki kuruluşlar dâhil KiT’lerin ürettiği katma değerin GSYH içindeki payının yüzde 0,8 olarak gerçekleşmesi öngörülmektedir (T.C. Kalkınma Bakanlığı, 2013: 79).

Tablo 1. Onuncu Kalkınma Planında KiT'lere İlişkin Seçilmiş Göstergelerde Gelişmeler ve Hedefler (GSYH'ya Oran, \%)

\begin{tabular}{|l|c|c|c|c|}
\hline & $\mathbf{2 0 0 6}$ & $\mathbf{2 0 1 2}$ & $\mathbf{2 0 1 3}$ & $\mathbf{2 0 1 8}$ \\
\hline Toplam Katma Değer & 1,9 & 1,3 & 1,2 & 0,8 \\
\hline Satış Hasılatı & 8,3 & 8,3 & 7,4 & 3,8 \\
\hline Sermaye Transferi & 0,6 & 0,3 & 0,4 & 0,2 \\
\hline Görev Zararı & 0,1 & 0,1 & 0,1 & 0,1 \\
\hline Temettü ve Hasılat Payı & 0,1 & 0,1 & 0,2 & 0,1 \\
\hline Yatırım & 0,5 & 0,5 & 0,7 & 0,4 \\
\hline Borçlanma Gereği $^{*}$ & 0,2 & 0,4 & 0,5 & 0,3 \\
\hline
\end{tabular}

Kaynak: T.C. Kalkınma Bakanlığı Onuncu Kalkınma Planı (2014-2018), 79.

Not:2006 ve 2012 yılı verileri Kalkınma Bakanlığı ve Hazine Müsteşarlığına aittir. 2013 ve 2018 yılı verileri Onuncu Kalkınma Planı tahminleridir.*Bütçe ve fon transferleri hariçtir.

OKP'de yer alan hedefler doğrultusunda özellikle toplam katma değer ve satış hasılatı oranları ile plan dönemi boyunca özelleştirmelerin devam edeceği ve KiT’lerin ekonomi içerisindeki payının azaltılacağı açık bir biçimde yer almaktadır. Onuncu Kalkınma Planında kamu işletmeciliğine yönelik politikalar şu şekilde sıralanabilmektedir:

- Özelleştirme kapsamındaki kuruluşlar dâhil kiт’lerin faaliyetleri, ekonomik amaç ve hedeflere dayalı olarak yürütülecektir. Devlet tarafından gerçekleştirilmesi zorunlu olan sosyal amaçlı ve kamu yararına yönelik faaliyetler için bu kuruluşların görevlendirilmesinden ziyade evrensel hizmet fonu oluşturulması gibi yöntemler öncelikli olarak değerlendirilecektir (T.C. Kalkınma Bakanlığı, 2013). Bu politikadan hareketle 2000 sonrası dönemde KiT’lerde benimsenen ekonomik amaçlara uygun yönlendirme politikasının devam ettiği ifade edilebilir.

Bu politikada yer alan evrensel hizmet kavramı "tüm bireylere, istisnasız makul kalite ve fiyattan, sürekli ve düzenli olarak sunulmak zorunda olunan ve çağdaş bir insan için vazgeçilmesi mümkün olmayan asgari/temel ortak ihtiyaçlar" olarak tanımlanabilir (Kabasakal ve Solak, 2008). Evrensel hizmet kavramı özellikle serbest piyasa ekonomisinin uygulandığı ülkelerde, sosyal refahın sağlanması amacı ile gündeme gelmiş bir kavramdır. Planda yer alan evrensel hizmet fonu oluşturulmasına yönelik politika ise kamu yararı işlevinin Kiт’lerden alınarak modern tekniklerle sağlanması yolunda adımlar atılması hedeflendiğini gözler önüne sermektedir. Türkiye ekonomisinde 1980 sonrası dönemde benimsenen neoliberal politikaların perçinlenmesine yönelik uygulamalara devam edildiği çıkarımında bulunulabilir.

- Kiт'lerin faaliyetleri, piyasa mekanizmasını bozucu etkiye neden olmayacak şekilde yürütülecektir. KiT’lerde verimliliğin, hesap verebilirliğin, karar süreçlerinde esnekliğin artırılmasını sağlayacak 
uluslararası kabul görmüş kurumsal yönetim ilkeleriyle uyumlu bir mevzuat düzenlemesi yapılacaktır. Stratejik yönetim anlayışı yaygınlaştırılacak, Kiт faaliyetlerinin stratejik planlar ve performans programlarına uyumunun artırımasına yönelik uygulamalar ile birlikte KiT'lerde etkili iç denetim ve iç kontrol mekanizması kurulacaktır. Dış denetim süreçleri, hesap verebilirlik anlayışı çerçevesinde etkinleştirilecektir (T.C. Kalkınma Bakanlığı, 2013). Bu politikalar değerlendirildiğinde birinci bölümde bahsedilen yeni kamu işletmeciliğine yönelik kavramların ağılıklı olarak yer aldığı görülmektedir. Öte yandan özel sektör temelli plan, performans ve denetim kavram ve uygulamalarının tüm kamu kurumlarında yaygınlaştırılması, piyasa odaklı kamu yönetiminin bir yansıması olarak değerlendirilebilir.

OKP'de yerel yönetimlere yönelik hedef ve politikalar değerlendirildiğinde; yerel yönetimlerin öz gelirlerinin artırılması (T.C. Kalkınma Bakanlığı, 2013: 76), yerel yönetimlerin mali yönden merkezi yönetime bağımlılığının azaltılması (T.C. Kalkınma Bakanlığı, 2013: 160) amaçları yer almaktadır. Ayrıca Öncelikli Dönüşüm Programları kapsamında Yerelde Kurumsal Kapasitenin Güçlendirilmesi Programı'na yer verilmektedir. Programın amacı, önceliklerin isabetli belirlenmesi, uygulamada kalitenin ve kaynak kullanımında verimliliğin artırılması ve kalkınma çabalarının güçlendirilmesi için yerel düzeyde kurumsal kapasitenin, katılımcılığın ve yönetişimin geliştirilmesi olarak ifade edilmektedir (T.C. Kalkınma Bakanlığı, 2013). Yeni kamu işletmeciliği yaklaşımında kamu hizmetlerinin sağlanmasında yerelleşme, verimlilik, etkinlik, şeffaflık ve hesap verebilirlik ilkelerine vurgu yapılmıştır (Alkan, 2018). Dolayısıyla OKP'de yerel yönetimlere yönelik konulan hedef ve politikaların yeni kamu işletmeciliğinin temel değerlerini içerdiği söylenebilir.

\subsection{On Birinci Kalkınma Planında Kamu İşletmeciliği}

On Birinci Kalkınma Planı (OBKP)'nda “Kamu İşletmeciliği ve Özelleştirme” başlığı altında "Kamu işletmelerinin faaliyetlerini, piyasa mekanizmasını bozucu etkiye neden olmayacak şekilde, kârlılık ve verimlilik ilkelerine dayalı olarak yürütmesi; sosyal amaçı ve kamu yararına yönelik faaliyetler için görevlendirilmeleri durumunda ise oluşacak maliyetlerin tam ve zamanında karşılanması ve faiz dışı açık vermemesi" amaç olarak yer almaktadır (T.C. Cumhurbaşkanlığı Strateji ve Bütçe Başkanlığı, 2019: 49). OBKP'de kamu işletmeciliğine yönelik politika ve tedbirlerden bazıları şu şekilde sıralanmaktadır:

- KiT’lerde istihdam edilecek personel sayısı özellikli durumlar haricinde artırılmayacaktır (T.C. Cumhurbaşkanlığı Strateji ve Bütçe Başkanlığı, 2019: 50). Bu doğrultuda günümüzde KiT’lere yönelik özellikle istihdam sağlama işlevinin geçmişe oranla sınırlandırılmasına yönelik politika tasarlandığı belirtilebilir.

- Kamu işletmelerinin üretim birimlerinde kapasite kullanım oranları artırılacak, mevcut tesislerinin kapasiteleri en üst düzeyde kullanılacak ve yeni yatırım tercihleri bu doğrultuda hayata geçirilecektir (T.C. Cumhurbaşkanlığı Strateji ve Bütçe Başkanlığı, 2019: 50). Bu tedbir ile birlikte KiT’lerde etkin çalışmanın sağlanması amaçlanmaktadır.

- Kіт’lerin fiyat ve tarifeleri ticari esaslara göre belirlenecek, sektörde serbestleşmeye ve rekabete engel olan uygulamalar kaldırılacaktır. Kamu işletmelerinde hesap verebilirlik güçlendirilecek ve şeffaflık artırılacaktır. KiT’lerde finansal raporlama ve bağımsız denetimin kalitesi artırılacaktır (T.C. Cumhurbaşkanlığı Strateji ve Bütçe Başkanlığı, 2019: 50).

- Etkin bir piyasa mekanizması oluşturma hedefi doğrultusunda özelleştirme uygulamalarına devam edilecektir. Plan döneminde özelleştirme portföyünde bulunan şirket ve varlıkların özelleştirilmesine devam edilecek, özelleştirilme potansiyeli olan yeni şirket ve varlıklar portföye dâhil edilerek özelleştirilecektir (T.C. Cumhurbaşkanlığı Strateji ve Bütçe Başkanlığı, 2019: 50-51). Türkiye ekonomisinde özellikle 1990'lı yılların sonundan itibaren uygulama alanı bulan özelleştirmelere günümüzde de genişletilerek devam edileceği ortaya konulmaktadır. Dolayısıyla piyasaların etkinliğini sağlayabilmek adına ve neoliberal politikaların devletin ekonomi içerisindeki payının küçültülmesine yönelik uygulamalar Plan dönemi boyunca sürdürülecektir. 
Yeni Kamu İşletmeciliği Bağlamında Kalkınma Planlarının Değerlendirilmesi: ARDL Sınır Testi Yaklaşımı

Tablo 2. On Birinci Kalkınma Planında KiT’lere İlişkin Hedefler (GSYH'ya Oran, \%)

\begin{tabular}{|l|c|c|}
\hline & $\mathbf{2 0 1 8}$ & $\mathbf{2 0 2 3}$ \\
\hline Toplam Katma Değer & 0,7 & 0,8 \\
\hline Satış Hasılatı & 3,4 & 2,9 \\
\hline Toplam Bütçe ve Fon Transferleri & 0,5 & 0,6 \\
\hline Temettü ve Hasılat Payı & 0,1 & 0,2 \\
\hline Yatırım & 0,5 & 0,7 \\
\hline Borçlanma Gereği ${ }^{*}$ & 0,5 & 0,5 \\
\hline
\end{tabular}

Not: Tablodaki veriler 233 sayılı Kanun Hükmünde Kararname kapsamındaki KiT’ler ile 4046 sayılı Kanun hükümleri çerçevesinde faaliyetlerini sürdüren kamu işletmelerini kapsamaktadır. 2023 yılı verileri On Birinci Kalkınma Planı tahminleridir. $\left({ }^{*}\right)$ Bütçe ve fon transferleri hariçtir.

Kaynak: T.C. Cumhurbaşkanlığı Strateji ve Bütçe Başkanlığı On Birinci Kalkınma Planı (2018-2023), 51.

Tablo 2'de OBKP'de KiT'lere ilişkin hedefler yer almaktadır. 2023 yılı tahminlerine bakıldığında oranların Plan dönemi sonuna kadar genel olarak sabit tutulmaya çalışıldığı görülmektedir. Toplam katma değerde hedeflenen \% 0,1'lik artışın mevcut kiт’lerin tam kapasite çalışma hedefinden kaynaklandığı düşünülmektedir. Satış hasılatındaki azalış tahmini ise KiT’lerin piyasadaki etkinliğinin azaltılması ile doğru orantılıdır.

Tablo 3. KiT Kâr-Zarar Tablosu (Cari Fiyatlarla, Milyon TL)

\begin{tabular}{|l|c|c|c|c|}
\hline & $\mathbf{2 0 1 6}$ & $\mathbf{2 0 1 7}$ & $\mathbf{2 0 1 8}$ & $\begin{array}{c}\text { \% Değişim } \\
\mathbf{( 2 0 1 8 -} \\
\mathbf{2 0 1 7}\end{array}$ \\
\hline Faaliyet Kâr-Zararı & & & - \\
\hline D. Faaliyetlerden Olağan Gelir ve Kârlar & $11.988,1$ & $11.130,8$ & $28.333,3$ & 154,5 \\
\hline D. Faaliyetlerden Olağan Gider ve Zararlar & $7.710,7$ & $9.056,9$ & $18.040,0$ & 99,2 \\
\hline Finansman Giderleri & 989,6 & $1.389,2$ & $3.519,3$ & 153,3 \\
\hline \multicolumn{1}{|c|}{-Faiz Giderleri } & 514,7 & 660,3 & $1.432,6$ & 117,0 \\
\hline \multicolumn{1}{|c|}{-Kur Farkları } & 247,8 & 424,0 & $2.078,9$ & 390,3 \\
\hline Olağandışı Gelir ve Kârlar & $5.422,4$ & $7.547,0$ & $9.208,1$ & 22,0 \\
\hline Olağandışı Gider ve Zararlar & $4.912,0$ & $3.005,4$ & $3.519,0$ & 17,1 \\
\hline Dönem Kâr- Zararı & $17.800,0$ & $7.677,4$ & $6.433,8$ & $-16,2$ \\
\hline $\begin{array}{l}\text { Dönem Kârı Vergi ve Diğer Yasal Yükümlülükler } \\
\text { Karşılıkları }\end{array}$ & $3.918,6$ & $2.397,5$ & $3.553,8$ & 48,2 \\
\hline Dönem Net Kâr-Zararı & $13.881,4$ & $5.279,9$ & $2.880,1$ & $-45,5$ \\
\hline Dönem Net Kâr- Zararı/GSYH (\%) & 0,53 & 0,17 & 0,08 & $-54,2$ \\
\hline
\end{tabular}

Kaynak: Kamu İ̧sletmeleri Raporu, 2018.

Tablo 3'te yer alan göstergelere bakıldığında faaliyet kârının tablodaki yıllarda sürekli azaldığı ve zarara dönüştüğü görülmektedir. Dönem kârındaki değişim de negatif olarak karşımıza çıkmaktadır. Dönem net kâr-zararı/GSYH oranının ise sürekli azalma eğiliminde olduğu söylenebilir. 2017 ve 2018 yılları oranındaki değişim ise \% 54,2 azalış olarak tabloda yer almaktadır. Dolayısıyla Kiт’lerin kârlılığında bir azalış olduğu aşikârdır. KiT’lere ilişkin diğer göstergelerden faiz dışı fazla ele alındığında 2016 yılında faiz dışı fazla/GSYH oranı \% 0,33 ve 2017 yılında \% 0,05 iken 2018 yılında \% -0,09 ile faiz dışı açığa dönüşmüştür. Ilave olarak işletmelerin, finansman giderlerinin kaç katı kazanç sağladığını ifade eden faizleri karşılama oranına bakıldığında, 2016 yılında 18,99, 2017 yılında 6,53 ve 2018 yılında 2,83 düzeyinde olduğu görülmektedir. Bu oranın yükselme eğiliminde olması finansman maliyetini karşılama kapasitesinin arttığı anlamına 
gelmektedir. Yıllar itibariyle Kiт faiz karşılama oranı düşüş gösterdiği için finansman maliyetini karşılama kapasitesinin daraldığı ifade edilebilmektedir (Hazine ve Maliye Bakanlığı, 2019). Buradan hareketle KiT’lerde finansman giderlerindeki artışın faiz dışı fazla üzerinde kendisini gösterdiği belirtilebilir.

Tablo 4. KiT’lerin Kârlılık Rasyoları (\%)

\begin{tabular}{|l|c|c|c|}
\hline & $\mathbf{2 0 1 6}$ & $\mathbf{2 0 1 7}$ & $\mathbf{2 0 1 8}$ \\
\hline Aktif Kârııık Oranı & 9,65 & 3,52 & 2,62 \\
\hline Özsermaye Kârııık Oranı & 13,34 & 4,21 & 2,02 \\
\hline Brüt Satış Kârı Oranı & 20,37 & 7,77 & 0,78 \\
\hline Faaliyet Kârı/Satışlar & 15,67 & 2,41 & $-4,89$ \\
\hline Vergi Öncesi Kâr/Satışlar & 19,92 & 7,54 & 5,22 \\
\hline Dönem Net Kârı/Satışlar & 15,54 & 5,18 & 2,34 \\
\hline
\end{tabular}

Kaynak: Kamu Işletmeleri Raporu, 2018.

Tablo 4'e bakıldığında KiT’lerin kârlılı̆ındaki azalmaya bağlı olarak kârlılık rasyolarının da bu duruma bağlı olarak azaldığı görülmektedir. Özellikle brüt satış kârı oranı 2016 yıında \%20,37 iken 2018 yıında \% 0,78 düzeyine gerilemiştir.

Yeni kamu işletmeciliğinin, geleneksel kamu yönetiminden paradigma olarak temel farkı, sonuç odaklııı ve hesap verebilirliğin sağlanmasıdır (Hughes, 2014). Yönetişim ile amaç, kamu işletmeciliği ile başlatılan piyasalaştırma girişimlerini, rekabet, etkinlik ve etkililik gibi ekonomik ölçütlere göre tanımlanan toplumsal ilişkiler alanına doğru genişletmektir (Güzelsarı, 2004). Buradan hareketle On Birinci Kalkınma Planında bu kavramların ağırlıklı olarak yer aldığı ve kamu yönetiminin yeni kamu işletmeciliği yaklaşımı ile buna bağı olarak yönetişim üzerine inşa edildiği belirtilebilir.

Yerel yönetimlerle ilgili olarak OBKP'de mali yapılarını güçlendirmek amacıyla öz gelirlerinin artırılacağı (T.C. Cumhurbaşkanlığı Strateji ve Bütçe Başkanlığı, 2019: 28) planın hedef ve politikaları arasında yer almaktadır. Plan bünyesinde "Kamu hizmetlerinin vatandaşa en yakın idari birimler eliyle yürütülmesi ve vatandaş memnuniyetinin üst düzeye çıkarılması için yerel yönetimlerin hizmet sunma kapasitesinin artırıması, daha şeffaf ve hesap verebilir bir yapıya kavuşturulması amaçlanmaktadır." (T.C. Cumhurbaşkanlığı Strateji ve Bütçe Başkanlığı, 2019: 189) ifadesi yer almaktadır. Buradan hareketle yeni kamu işletmeciliğinde yerelleşme üzerinde sıklıkla durulan bir kavram olduğu için incelenen kalkınma planlarında yer alıyor olması da yeni kamu işletmeciliğinin yansımaları olarak değerlendirilebilir.

\section{Model Uygulaması ve Ampirik Sınama}

Yeni kamu işletmeciliği anlayışı çerçevesinde kamu işletmelerindeki uygulama farklılıkları önceki başlıklarda ifade edilmiştir. Türkiye'de de gerek planlar gerekse alt uygulama politika metinlerinde kamu işletmelerine özellikle de KiT’lere ilişkin algı değişikliği günümüze gelinen süreçte belirtilmiştir. KiT işletim ve sürdürülebilirlik konularındaki algı, ekonomiye ve kamu maliyesine yük yaratmayacak bir sistemin inşasının oluşturulma gereği üzerinedir. Performanslarının artırılması, maliyet yüklerinin azaltılması, kârlılıklarının artırıması ve modern işletim sistemlerine kavuşturma gibi bir dizi hedef planlarda da vurgulanmıştır. Özelleştirme çalışmaları da bu hedefler dahilinde şekillenmektedir.

Bütün bu unsurların yanı sıra kamu iktisadi teşebbüslerinin ekonomiye katkılarından da bahsedilmesi gerekmektedir. Kamu sermayeli oluşları, amaç setlerinin farklılı̆̆ı, işletim sistemlerinin farklılığı gibi unsurlar çerçevesinde değerlendirilerek yorum yapılması önemlidir. Katma değer kavramından bahsedilmekte ancak bunun ileri ve geri bağlantıları çok fazla ifade edilmemektedir. KiT'lerin alt sektörler itibariyle ve dolayısıyla makroekonomik olarak katkıları fayda - maliyet analizleri çerçevesinde değerlendirilmelidir. Bu çalışmada model kurgusu girdi - çıktı ilişkisi ile doğrudan sektör analizleri yapmak yerine, Kiт katma değerleri ve sektörel büyüme arasındaki ilişkiyi test etmeyi amaçlamaktadır. 
Model çalışmasında kamu iktisadi teşebbüslerinde yaratılan katma değerin, sektörel büyüme hızlarına etkileri araştırılmaktadır. Söz konusu işletmelerin faaliyet gösterdiği tarım ve sanayi alt sektörleri büyüme performansları açısından ayrı ayrı incelenmektedir. Kamu işletmeciliği ana başlığı altında veri seti düzenli ve geçmişe dönük olduğu için kamu iktisadi teşebbüsleri sınamaya alınmıştır. Modelin kurgusunda alt sektörleri etkileyen diğer unsurlar sabit tutulmuştur. Sınama denklemleri de girdi - çıktı analizleri çerçevesinde GSYH'yı etkileyen unsurlar çerçevesinde değerlendirilmiştir.

\subsection{Değişkenler ve Uygulama Modeli}

\subsubsection{Değişkenler}

Konu ile ilgili değişkenler; kamu iktisadi teşebbüsleri katma değeri, tarım ve sanayi sektörü büyüme hızlarıdır. Katma değer GSYH'ye oran olarak alınmıştır ve sektör büyüme hızlarına uyumlu olması açısından bir önceki yıl değişim şeklinde düzenlenmiştir. Verilerin dönem aralıkları 1985-2017 ve yıllık veriler şeklindedir. Değişkenlerin kaynak bilgileri Tablo 5'te verilmiştir.

Tablo 5. Model Değişkenleri Kaynak ve Dönem Bilgileri

\begin{tabular}{|l|l|c|}
\hline & Kaynak & Dönem \\
\hline İşletmeci Kiт Katma Değer (kd) & Strateji ve Bütçe Başkanlığı & $1985-2017$ \\
\hline Tarım Sektörü Büyüme Hızı (tarımb) & Strateji ve Bütçe Başkanlığı & $1985-2017$ \\
\hline Sanayi Sektörü Büyüme Hızı (sanayib) & Strateji ve Bütçe Başkanlığı & $1985-2017$ \\
\hline
\end{tabular}

\subsubsection{Uygulama Modeli Açıklamalar}

Çalışmada değişkenler arasındaki uzun dönemli ilişkiler (eşbütünleşme) araştırılmaktadır. Eşbütünleşme analizi; uzun dönem ilişkiyi anlatan, serilerde dengenin varlığını gösteren ve değişkenlerin kısauzun dönem bilgileri ile hata düzeltme modellerini içeren istatistiksel ve ekonomik zemini oluşturmaktadır (Karayılmazlar ve Özgün, 2019: 502-503). Geleneksel eşbütünleşme testleri (Engle-Granger (1987), Johansen (1988) ve Johansen-Juselius (1990)) eşbütünleşme durumları sınanan parametrelerin durağanlık durumlarının düzeyde $\left(I_{0}\right)$ olmaması ancak birinci sıra farkta $\left(I_{1}\right)$ durağan olmasını zorunlu tutmaktadır (Pesaran, Shin ve Smith, 2001). Buna karşı, Pesaran vd. (2001) çalışması parametreler farklı durağanlık düzeylerinde de olsa eşbütünleşme analizlerinin yapılmasının mümkün olduğunu ifade etmiştir.

ARDL modeli, farklı durağanlık düzeylerine sahip parametreler arasında eşbütünleşme analizi yapılmasını sağlayan modelidir. Bu model; farklı durağanlık düzeylerine sahip değişkenler için sınır testi ve kısıtsız hata düzeltme modeli uygulamalarını mümkün kılmakta ve diğer modellere göre istatistiksel olarak daha anlamlı ve güvenilirdir (Kamacı ve Kara, 2019). Modelin diğer uygulamalara göre; gecikme uzunluğu EKK ile belirlendikten sonra eşbütünleşmeyi araştırması açısından kolay olması, birim kök sınamasına alınan değişkenlerin ön testlerinin yapılmasına gerek olmaması, durağanlığın tümüyle $I(0)$ ve $\left.I_{(}\right)$ya da tümünün karşılıklı eşbütünleşik $I_{1}$ ) olup olmadığına bakılmaksızın uygulanabilmesi ve sınırlı örnek kümeler için etkin olması gibi avantajları bulunmaktadır (Altıntaş, 2013).

Eşbütünleşmenin analizi sonrasında nedensellik testi yapılacak burada da durağanlık dereceleri farklı değişkenler arasındaki nedensellik araştırabilen Toda-Yamamoto (1995) testi kullanılacaktır. Geleneksel Granger Nedensellik testinden farklı olarak TY yaklaşımında farklı durağanlık düzeylerinde de olsa değişkenlerin arasındaki nedensellik ilişkisi araştırılabilmektedir (Kamacı ve Kara, 2019). Toda ve Yamamoto(1995), Granger nedensellik analizinde kullanılan $F$ testinin, serilerin durağan olmadığı durumda, geleneksel F-istatistiği standart dağılıma sahip olmayacağı için geçerli olmayabileceğini, seriler durağan olmasalar da serilerin düzey değerlerinin yer aldığı VAR modelinin tahmin edilebileceğini ve standart Wald testinin uygulanabileceğini, Granger nedensellik testi için, serinin durağan, trend etrafında durağan veya eşbütünleşik olup olmadığı dikkate alınmaksızın $[k+(d m a x)]$ dereceden VAR model tahmin edileceği $k$, tahmin edilen VAR modelinin uygun gecikme uzunluğunu, dmax ise modeldeki değişkenlerin maksimum bütünleşme 
derecesini ifade edeceğini, yöntemin başarısının, sistemin gecikme uzunluğu(k) ve serilerin bütünleşme derecelerinin (dmax) doğru tespitine bağlı olduğunu ve yöntemin kullanımı ile serilerin bütünleşme derecesinin yanlış tespit edilmesi ile ilgili riskleri minimize ettiğini ifade etmektedir (Yavuz, 2006: 169).

\subsection{Uygulama Sonuçları}

Uygulama sonuçları iki ayrı model sonuçları şeklinde verilecektir. Öncelikle tarım sektörü ardından da sanayi sektörü açısından bulgular değerlendirilecektir. Uygulamalar; durağanlık analizi, ARDL Sınır Testi ve ardından nedensellik testi şeklinde gerçekleştirilecektir.

Değişkenlerin durağanlık derecelerine bakılması önceliklidir. Modelde ele alınan değişkenlerin yıl seri uzunluğu açısından geleneksel birim kök testlerinden farklı olarak kırılma dönemlerinin dikkate alındığı yöntemle durağanlık analizinin yapılması gerekmektedir. Analizin ele alındığı 1985-2017 yılları arasında ekonomik, siyasi ve sosyal olaylar yapısal kırılmalara neden olabilmekte ve bunun için Zivot-Andrews Yapısal Kırılmalı Birim Kök testi uygulanması gerekmektedir. Bu sonuçlara göre durağanlık dereceleri aynı olan değişkenlerle yapılacak olan sınamada hata çıkması olasılı̆̆ına karşı durağanlık düzeyleri farklı değişkenlere uygulanacak ve eşbütünleşme durumlarına bakılacak ARDL modelinin kurulması için gerekli şartlar sağlanmış olmaktadır. Kurulan ARDL model sonucu ortaya çıkan F istatistik değeri sınır testine tabi tutularak değişkenler arasında uzun dönem eşbütünleşme olup olmadığına bakılacaktır.

Modelin değişkenlerinin eşbütünleşik ve istikrarlı olduğunun belirlenmesinin ardından aralarındaki nedenselliğin sınanması gerekmektedir. Bunun için daha önce ifade edilen ve farklı durağanlık seviyelerine sahip değişkenler arasındaki nedenselliği sınayan Toda - Yamomoto Testi uygulanacaktır. Daha önce açıklandığı üzere TYT' $d$ e $d_{\max }$ ve $k$ değerlerinin toplamı kadar gecikmeyle VAR modeli oluşturularak tahminler yapılmakta ve nedensellik araştırılmaktadır.

\subsection{1. кіт Katma Değerinin Tarım Sektörü Büyüme Hızına Etkisine İlişkin Model (Birinci Model)}

\section{Birinci Model İçin Durağanlık, ARDL Modeli Sınır Testi (Tarım Sektörü)}

İ̧letmeci Kiт katma değerinin tarım sektörü büyüme hızına etkisinin araştırıldığı birinci model için değişkenlerin durağanlık durumu önce geleneksel ADF ve daha sonra da yapısal kırılma dönemleri olduğu düşünülerek ZA birim kök testleri ile aşağıdaki tablolarda gösterilmiştir.

Tablo 6. ADF Birim Kök Test Sonuçları

\begin{tabular}{|c|c|c|c|c|c|c|}
\hline Değişkenler & & \multicolumn{2}{|c|}{ Tarımb } & Karar & $\Delta \mathbf{k d}$ & Karar \\
\hline t-İstatistiği (prob) & \multirow{4}{*}{ C } & & 12683* & \multirow{4}{*}{$\mathrm{I}(0)$} & $-6,505742^{*}$ & \multirow{4}{*}{$\mathrm{I}(0)$} \\
\hline \multirow{3}{*}{ Kritik Değerler } & & $\% 1$ & $-3,653730$ & & $-3,711457$ & \\
\hline & & $\% 5$ & $-2, .957110$ & & $-2,981038$ & \\
\hline & & $\% 10$ & $-2,617434$ & & $-2,629906$ & \\
\hline $\mathrm{t}$-i̇statistiği & \multirow{4}{*}{$C+T$} & & 54411 & \multirow{4}{*}{$\mathrm{I}(1)$} & $-6,350969$ & \multirow{4}{*}{$\mathrm{I}(0)$} \\
\hline \multirow{3}{*}{ Kritik Değerler } & & $\% 1$ & $-4,323979$ & & $-4,356068$ & \\
\hline & & $\% 5$ & $-3,580623$ & & $-3,595026$ & \\
\hline & & $\% 10$ & $-3,225334$ & & $-3,233456$ & \\
\hline
\end{tabular}

*MacKinnon (1996) one-sided p-values (\%1)

Birinci model için değişkenlerin durağanlık durumlarının incelendiği ADF testi sonuçları hem trendsiz hem de trendli model olarak çıkarılmışır. Model tahminlerinde modified akaike (MAIC) bilgi kriteri kullanılmıştır. Tarım sektörü büyüme hızı değişkeni ADF kritik değer karşılaştırmalarında trendsiz modelde boş hipotez red çıkarak düzeyde durağan, trendli modelde ise boş hipotez kabul çıkarak düzeyde durağan çıkmamış ve birinci sıra farkı alındığında fark durağan çıkmıştır. Katma değer değişkeni ise başlangıçta hem 
trendli hem de trendsiz model için boş hipotez kabul çıkarak düzeyde durağan çıkmamış, birinci sıra farkı alındığında hem trendli hem de trendsiz model için fark durağan çıkmıştır.

Standart birim kök test sonuçlarının, çalışmalarda ele alınan örnek dönemi içinde önemli olayların gerçekleşmesi durumunda bundan etkileneceği ve serilerde yapısal kırılmaların varlığı durumunda, söz konusu testlerin birim kök temel hipotezinin kabulüne doğru eğilimli olduğunu ifade edilmiştir (Yavuz, 2006: 165). Çalışmanın ele alındığı yıl aralığı dikkate alındığında kamu iktisadi teşebbüsleri ve Türkiye'deki makroekonomik düzenlemeler açısından çok sayıda değişiklik ve sonuçları etkileyecek durumun varlığı düşünüldüğünden yapısal kırılmaların olup olmadığına ilişkin geleneksel birim kök testleri dışında yapısal kırılmaları dikkate alan Zivot - Andrews yapısal kırılmalı birim kök testinin yapılması planlanmıştır. Zivot Andrews modelinin üstünlüğü, yapısal kırılmayı içsel olarak kabul etmesidir (Yavuz, 2006: 165).

Tablo 7. Zivot-Andrews Yapısal Kırılmalı Birim Kök Test Sonuçları

\begin{tabular}{|l|c|c|}
\hline k=8 & Tarımb & Kd \\
\hline Kırılma Dönemi & 2010 & 2005 \\
\hline t- istatistik değerleri (prob*) & $-11,87426^{*}$ & $-5,178568^{*}$ \\
\hline Seçilen gecikme uzunluğu & 5 & 5 \\
\hline Kritik Değerler & & \\
\hline$\% 1$ & $-4,949133$ & $-4,949133$ \\
\hline$\% 5$ & $-4,443649$ & $-4,443649$ \\
\hline
\end{tabular}

*Vogelsang (1993) asymptotic one-sided p-values (\%1)

Yapısal kırılmalar dikkate alındığında tarım sektörü büyüme hızı değişkeni için 2010 ve katma değer değişkeni için ise 2005 yılında yapısal kırılma durumu söz konusudur. Değişken parametre tahminlerinin ZA kritik değerleri ile karşılaştııılması sonucu \%1 anlamlılık düzeyinde boş hipotez reddedilerek her iki değişkenin de düzeyde durağan oldukları görülmektedir. Her iki değişkene ait durağanlık için modified akaike (MAIC) bilgi kriteri kullanılmıştır. Bir yapısal kırılmalı model tahmini sonuçlarına göre her iki değişkene ait yapısal kırılmaların değişkenlerde kalııı etki yaratmadığı görülmektedir.

Yapısal kırılmaların kalıcı etkisinin olmaması ve değişkenlerin yapısal kırılma olmaksızın durağanlık düzeylerinin farklılı̆̆ geleneksel eşbütünleşme tahmini analizlerinin kullanım imkanını ortadan kaldırdığından bu çalışmada ARDL Sınır Testi yaklaşımının uygulanmasına karar verilmiştir. ARDL analizi; değişkenlerin kısa ve uzun dönemli ilişkilerinin belirlenmesinde tüm değişkenlerin ikinci sıra fark durağan olması dışında, bütünüyle düzeyde durağan, birinci sıra fark durağan ya da tümünün karşılıklı eşbütünleşik birinci sıra fark durağan olup olmadığına bakılmaksızın analiz yapılmasına imkan vermektedir (Pesaran vd., 2001'den aktaran Yamaçı ve Saatçi, 2016: 60). Diğer bir ifadeye söz konusu test ile değişkenlerin bütünleşme derecelerine bakılmadan uzun dönem ilişkileri araştırılabilmektedir (Kıran ve Güriş, 2011: 72).

ARDL modelin kurulmasından önce uygun gecikme uzunluğunun belirlenmesi gerekmektedir. Gecikme uzunluğu belirleme işlemi için maksimum gecikme ile tahmin edilen modellerden AIC ve SC bilgi kriterlerine göre ve otokorelasyon olmayan modelin seçimi önemlidir. AIC ve SC bilgi kriteri değerlerinin en düşük olduğu ve LM istatistiği olasılık derecesi olarak otokorelasyonun olmadığını işaret eden maksimum gecikme uzunluğu değeri 9 olarak alınmıştır. Model 1 için uygun gecikme uzunluğu 7 olarak belirlenmiştir. Belirlemede SC bilgi kriteri dışındaki tüm kriterlerden yararlanılmıştır.

Uygun gecikme uzunluğu belirlendikten sonra ARDL modeline geçilir. Burada öncelikle sınır testi ile uzun dönem ilişkisi ardından da kısa dönem hata düzeltme modeli gerçekleştirilecektir. Modelin durağanlık sorunu için ters kök birim çember konumu gösteriminde, konum çember içinde kaldığında modelde durağanlık açısından herhangi bir sorun bulunmamaktadır.

ARDL modeli için kurulacak hata düzeltme modeli aşağıda gösterilmiştir. 
$\operatorname{TARIM}_{t}=\beta 0+\sum_{i=1}^{m} \beta 1_{i} \operatorname{TARIM}_{t-1}+\sum_{i=0}^{m} \beta 2_{i} \Delta K D t-_{i}+\theta 1 T A R I M B_{t-1}+\theta 2 K D_{t-1}+\varepsilon_{t}$

Denklemde $\beta 1$ i ve $\beta 2$ i katsayıları seriler arasındaki kısa dönem ilişkileri, $\theta 1$ ve $\theta 2$ ise uzun dönem ilişkileri açıklamaktadır.

ARDL modellerindeki kritik değerler Pesaran vd. tarafından geliştirilmiştir. Modellerde gözlem sayısı küçükse Pesaran vd. tarafından ifade edilen kritik değerler sapma gösterebilmekte, eşbütünleşme ilişkisinin saptanmasında yanıltıcı olabilmektedir, dolayısıyla 30-80 gözlem sayısına uygun olarak Narayan (2005) tarafından türetilen sınır testi için alt ve üst kritik değerlere de bakılması gerekmektedir (Altıntaş, 2013: 13).

Tablo 8. ARDL Sınır Testi Sonuç Karşılaştırması

\begin{tabular}{|c|c|c|c|c|c|c|c|c|c|c|c|c|c|}
\hline $\mathbf{k}$ & F istatistiği & \multicolumn{12}{|c|}{ Kritik Değer } \\
\hline \multirow{4}{*}{1} & \multirow{4}{*}{5,166251} & \multicolumn{6}{|c|}{ Pesaran vd. } & \multicolumn{6}{|c|}{ Narayan } \\
\hline & & \multicolumn{3}{|c|}{$I(0)$} & \multicolumn{3}{|c|}{ I(1) } & \multicolumn{3}{|c|}{$I(0)$} & \multicolumn{3}{|c|}{ I(1) } \\
\hline & & $\% 1$ & $\% 5$ & $\% 10$ & $\% 1$ & $\% 5$ & $\% 10$ & $\% 1$ & $\% 5$ & $\% 10$ & $\% 1$ & $\% 5$ & $\% 10$ \\
\hline & & 4,81 & 3,15 & 2,44 & 6,02 & 4,11 & 3,28 & 5,15 & 3,53 & 2,91 & 6,26 & 4.42 & 3,69 \\
\hline
\end{tabular}

Sınır testi sonuçları ve asimptotik değerlerle karşılaştırma Tablo 8'de gösterilmiştir. Tablodaki değerlerden $\mathrm{F}$ istatistik değeri, hem Pesaran vd. hem de Narayan asimptotik kritik değerler açısından, \%5 anlamlılık düzeyinde eşbütünleşmenin olduğunu işaret etmektedir. Eşbütünleşmenin varlığının belirlenmesinin ardından ARDL modeli uzun ve kısa dönem tahmin sonuçlarına bakılarak eşbütünleşme derecelerinin yorumlanması gerekmektedir. ARDL modeli için kurulan denklem aşağıdaki gibidir.

$$
\operatorname{TARIMB}_{t=} \beta 0+\sum_{i=1}^{m} \beta i_{1} \operatorname{TARIMB}_{t-1}+\sum_{i=0}^{n} \beta i_{2} K D_{t-1}+\varepsilon_{t}
$$

Tablo 9. Uzun Dönem ARDL $(2,4)$ Model Tahmin Sonuçları

\begin{tabular}{|c|c|c|}
\hline \multirow{2}{*}{ Bağımsız Değişkenler } & Katsayılar & t-istatistiği \\
\hline & \multicolumn{2}{|c|}{ Bağımlı Değişken: TARIMB } \\
\hline KD & 0,283028 & $11,941621 *$ \\
\hline $\mathbf{R}^{2}$ & \multicolumn{2}{|c|}{0,89} \\
\hline Düzeltilmiş $\mathbf{R}^{2}$ & \multicolumn{2}{|c|}{0,79} \\
\hline $\mathrm{LM}_{\mathrm{x}}$ & \multicolumn{2}{|c|}{0,18} \\
\hline $\mathrm{X}_{\mathrm{JB}}$ & \multicolumn{2}{|c|}{0,79} \\
\hline$X_{H}$ & \multicolumn{2}{|c|}{0,62} \\
\hline$X_{\text {WHITE }}$ & \multicolumn{2}{|c|}{0,44} \\
\hline $\mathrm{X}_{\mathrm{BPG}}$ & \multicolumn{2}{|c|}{0,36} \\
\hline $\mathbf{X}_{\mathrm{G}}$ & \multicolumn{2}{|c|}{0,35} \\
\hline $\mathbf{X}_{\text {ARCH }}$ & \multicolumn{2}{|c|}{0,55} \\
\hline
\end{tabular}

Sabitsiz ve trendsiz olarak tahmin edilen uzun dönem ARDL model tahmin sonuçları Tablo 9'da görülmektedir. Tablodaki sonuçlara göre bağımsız değişken bağımlı değişkenle uzun dönem etkileşim içindedir. \%1 anlamlılık düzeyi bulunmaktadır. Etki pozitiftir. Diğer bir ifadeyle KiT katma değerdeki \%1'lik artış, tarım sektörü büyüme hızını \%0,28 artırmaktadır. Modelin güvenilirlik test sonuçlarında göre de değişen varyans ve otokorelasyon sorunu yoktur ve normallik varsayımı açısından da problem bulunmamaktadır. 
Tablo 10. Kısa Dönem ARDL Hata Düzeltme Modeli Sonuçları

\begin{tabular}{|c|c|c|}
\hline Değişkenler (Bağımlı Değişken TARIMB) & Katsayılar & t-istatistiği \\
\hline $\mathrm{D}(\mathrm{TARIMB}(-1))$ & $-0,369178$ & $-1,995378$ \\
\hline $\mathrm{D}(\mathrm{KD})$ & 0,041791 & 1,022008 \\
\hline $\mathrm{D}(\mathrm{KD}(-1))$ & $-0,262103$ & $-3,612716$ \\
\hline $\mathrm{D}(\mathrm{KD}(-2))$ & $-0,151791$ & $-2,484909$ \\
\hline $\mathrm{D}(\mathrm{KD}(-3))$ & $-0,106689$ & $-2,353536$ \\
\hline $\mathrm{D}(\mathrm{SERO1})$ & $-5,050274$ & $-1,388844$ \\
\hline CointEq(-1) & $\mathbf{- 0 , 6 2 3 8 4 7}$ & $-3,627800 *$ \\
\hline
\end{tabular}

ARDL hata düzeltme modeli kısa dönem sonuçları tabloda görülmektedir. İstatistiksel olarak negatif olması beklenen hata düzeltme modeli bu çalışmada da \%1 önem düzeyinde istatistiksel olarak anlamlı ve negatif işaretlidir. Kısa dönemdeki dengesizlik uzun dönemde ortadan kalkmaktadır. Bu aşamada ARDL modeli parametrelerine yönelik istikrar ve yapısal kırılma durumlarındaki sınamayı göstermesi açısından CUSUM ve CUSUMSQ testlerinin görülmesi gerekmektedir.

Şekil 1. CUSUM ve CUSUMSQ Testleri
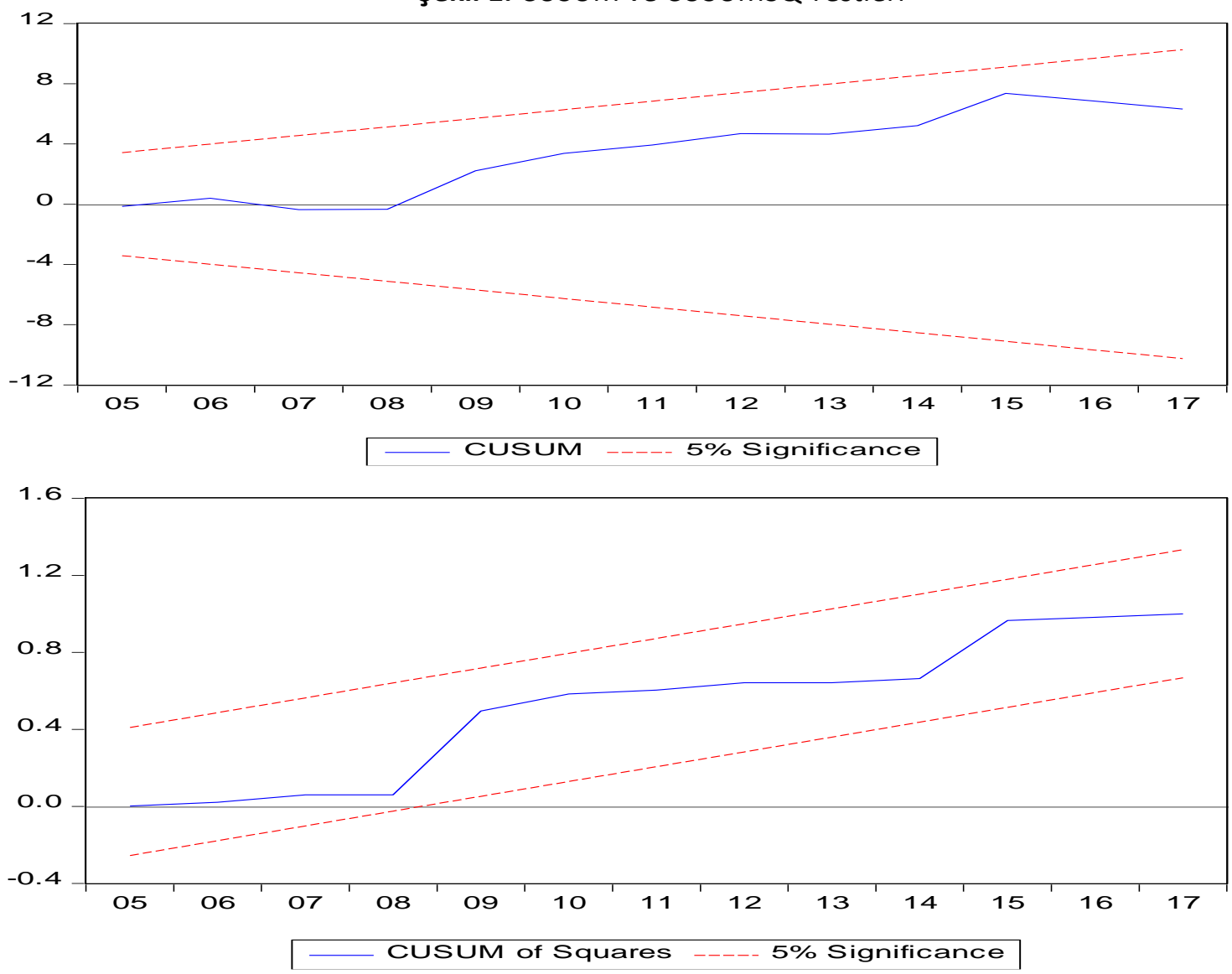

Şekilde görüldüğü üzere dağıım sınırlar içinde kaldığından model istikrarlıdır. Parametreler kararlıdır ve yapısal değişme yoktur.

\section{Toda - Yamomoto Nedensellik Analizi}

Modelde $d_{\max }$ yani maksimum bütünleşme derecesi 0 ve gecikme uzunluğu yani $k=7$ olarak alınmıştır. 
Tablo 11. TYT Sonuçları ve Nedensellik Durumu

\begin{tabular}{|l|c|}
\hline Hipotezler (Boş) & Kikare Değerleri \\
\hline KD, TARIMB'nin Granger Nedeni Değildir & $31,39305^{*}$ \\
\hline TARIMB, KD’nın Granger Nedeni Değildir & $8,457823^{* *}$ \\
\hline
\end{tabular}

Tablo 11 değerleri incelendiğinde tüm boş hipotezlerin reddedildiği dolayısıyla nedensellik ağının kurulduğu görülmektedir. Kiт katma değeri \%1 anlamlılık düzeyinde tarım sektörü büyüme hızı üzerinde nedensellik ilişkisine sahiptir. Değişkenler arasında karşılıklı nedensellik saptanmıştır.

\subsection{2. Кіт Katma Değerinin Sanayi Sektörü Büyüme Hızına Etkisine İlişkin Model (íkinci Model)}

\section{ikinci Model İçin Durağanlık, ARDL Modeli Sınır Testi (Sanayi Sektörü)}

İşletmeci Kiт katma değerinin sanayi sektörü büyüme hızına etkisinin araştırıldığı ikinci model için değişkenlerin durağanlık durumu önce geleneksel ADF ve daha sonra da yapısal kırılma dönemleri olduğu düşünülerek ZA birim kök testleri ile aşağıdaki tablolarda gösterilmiştir.

Tablo 12. İkinci Model ADF Birim Kök Test Sonuçları

\begin{tabular}{|c|c|c|c|c|c|c|}
\hline Değişkenler & & \multicolumn{2}{|c|}{ Sanayıb } & Karar & $\Delta \mathbf{k d}$ & Karar \\
\hline t-İstatistiği (prob) & \multirow{4}{*}{ C } & \multicolumn{2}{|c|}{$-5,387943^{*}$} & \multirow{4}{*}{$I(0)$} & $-6,505742^{*}$ & \multirow{4}{*}{$\mathrm{I}(0)$} \\
\hline \multirow{3}{*}{ Kritik Değerler } & & $\% 1$ & $-3,653730$ & & $-3,711457$ & \\
\hline & & $\% 5$ & $-2,957110$ & & $-2,981038$ & \\
\hline & & $\% 10$ & $-2,617434$ & & $-2,629906$ & \\
\hline t-İstatistiği & \multirow{4}{*}{$\mathrm{C}+\mathrm{T}$} & \multicolumn{2}{|c|}{$-5,293195$} & \multirow{4}{*}{$I(0)$} & $-6,350969$ & \multirow{4}{*}{$\mathrm{I}(0)$} \\
\hline \multirow{3}{*}{ Kritik Değerler } & & $\% 1$ & $-4,273277$ & & $-4,356068$ & \\
\hline & & $\% 5$ & $-3,557759$ & & $-3,595026$ & \\
\hline & & $\% 10$ & $-3,212361$ & & $-3,233456$ & \\
\hline
\end{tabular}

*MacKinnon (1996) one-sided p-values (\%1)

ikinci model için değişkenlerin durağanlık durumlarının incelendiği ADF testi sonuçları hem trendsiz hem de trendli model olarak çıkarılmıştır. Model tahminlerinde modified akaike (MAIC) bilgi kriteri kullanılmıştır. Sanayi sektörü büyüme hızı değişkeni ADF kritik değer karşılaştırmalarında trendli ve trendsiz modelde boş hipotez red çıkarak düzeyde durağan çıkmıştır. Katma değer değişkeni ise başlangıçta hem trendli hem de trendsiz model için boş hipotez kabul çıkarak düzeyde durağan çıkmamış, birinci sıra farkı alındığında hem trendli hem de trendsiz model için fark durağan çıkmıştır.

Tablo 13. İkinci Model Zivot-Andrews Yapısal Kırılmalı Birim Kök Test Sonuçları

\begin{tabular}{|l|c|c|}
\hline k=8 & Sanayıb & Kd \\
\hline Kırılma Dönemi & 2009 & 2005 \\
\hline t- istatistik değerleri(prob*) & $-6,226436^{*}$ & $-5,178568^{*}$ \\
\hline Seçilen gecikme uzunluğu & 5 & 5 \\
\hline Kritik Değerler & & \\
\hline$\% 1$ & $-4,949133$ & $-4,949133$ \\
\hline$\% 5$ & $-4,443649$ & $-4,443649$ \\
\hline
\end{tabular}

*Vogelsang (1993) asymptotic one-sided p-values (\%1) 
Önceki modelde olduğu gibi yapısal kırılmalar dikkate alındığında sanayi sektörü büyüme hızı değişkeni için 2009 ve katma değer değişkeni için ise 2005 yılında yapısal kırılma durumu söz konusudur. Değişken parametre tahminlerinin ZA kritik değerleri ile karşılaştırılması sonucu \%1 anlamlılık düzeyinde her iki değişkenin de düzeyde durağan oldukları görülmektedir. Bir yapısal kırılmalı model tahmini sonuçlarında iki değişkene ait yapısal kırılmaların değişkenlerde kalıcı etki yaratmadığı görülmektedir.

ARDL modeli kurulmadan önce uygun gecikme uzunluğu belirlenecektir. Bunun için maksimum gecikme ile tahmin edilen modellerden AIC ve SC bilgi kriterlerine göre ve otokorelasyon olmayan model seçilecektir. AIC ve SC bilgi kriteri değerlerinin en düşük olduğu ve LM istatistiği olasılık derecesi olarak otokorelasyon içermeyen maksimum gecikme uzunluğu değeri 10 olarak alınmıştır. Model 2 için uygun gecikme uzunluğu 10 olarak belirlenmiştir. Belirlemede SC bilgi kriteri dışındaki tüm kriterlerden yararlanılmıştır. Modelin durağanlık sorunu için ters kök birim çember konumu gösterimi yapılmaktadır. Ters kök birim çember konumu çember içinde kaldığında modelde durağanlık açısından herhangi bir sorun da bulunmamaktadır.

İkinci modele ait ARDL hata düzeltme modeli aşağıda gösterilmiştir.

$$
\operatorname{SANAYI}_{t}=\beta 0+\sum_{i=1}^{m} \beta 1_{i} \operatorname{SANAYIB}_{t-1}+\sum_{i=0}^{m} \beta 2_{i} \Delta K D t-_{i}+\theta 1 \operatorname{SANAYIB}_{t-1}+\theta 2 K D_{t-1}
$$

Denklemde $\beta 1$ i ve $\beta 2 i$ katsayıları seriler arasındaki kısa dönem ilişkileri, $\theta 1$ ve $\theta 2$ ise uzun dönem ilişkileri açıklamaktadır.

Tablo 14. İkinci Model ARDL Sınır Testi Sonuç Karşılaştırması

\begin{tabular}{|c|c|c|c|c|c|c|c|c|c|c|c|c|c|}
\hline $\mathbf{k}$ & $\mathrm{F}$ istatistiği & \multicolumn{12}{|c|}{ Kritik Değer } \\
\hline \multirow{4}{*}{1} & \multirow{4}{*}{6,910596} & \multicolumn{6}{|c|}{ Pesaran vd. } & \multicolumn{6}{|c|}{ Narayan } \\
\hline & & \multicolumn{3}{|c|}{$I(0)$} & \multicolumn{3}{|c|}{ I(1) } & \multicolumn{3}{|c|}{$I(0)$} & \multicolumn{3}{|c|}{ I(1) } \\
\hline & & $\% 1$ & $\% 5$ & $\% 10$ & $\% 1$ & $\% 5$ & \%10 & $\% 1$ & $\% 5$ & \%10 & \%1 & $\% 5$ & \%10 \\
\hline & & 4,81 & 3,15 & 2,44 & 6,02 & 4,11 & 3,28 & 5,15 & 3,53 & 2,91 & 6,26 & 4,42 & 3,69 \\
\hline
\end{tabular}

İkinci model için sınır testi sonuçları ve asimptotik değerlerle karşılaştırma Tablo 14'de gösterilmiştir. Tablodaki değerlerden $\mathrm{F}$ istatistik değeri, hem Pesaran vd. hem de Narayan asimptotik kritik değerler açısından, \%1 anlamlılık düzeyinde eşbütünleşmenin olduğunu işaret etmektedir.

ARDL modeli için kurulan denklem aşağıdaki gibidir.

$$
\operatorname{ANAYIB}_{t=} \beta 0+\sum_{i=1}^{m} \beta i_{1} \operatorname{SANAYIB}_{t-1}+\sum_{i=0}^{n} \beta i_{2} K D_{t-1}+\varepsilon_{t}
$$

Tablo 15. İkinci Model Uzun Dönem ARDL $(1,4)$ Model Tahmin Sonuçları

\begin{tabular}{|c|c|c|}
\hline \multirow{2}{*}{ Bağımsız Değişkenler } & Katsayılar & t-istatistiği \\
\cline { 2 - 3 } & \multicolumn{2}{|c|}{ Bağımlı Değişken: Sanayıb } \\
\hline KD & 0,372883 & $9,438389 *$ \\
\hline $\mathbf{R}^{\mathbf{2}}$ & \multicolumn{2}{|c|}{0,78} \\
\hline Düzeltilmiş $\mathbf{R}^{\mathbf{2}}$ & \multicolumn{2}{|c|}{0,63} \\
\hline $\mathbf{L M}_{\mathbf{x}}$ & 0,75 \\
\hline $\mathbf{X}_{\mathrm{JB}}$ & 0,76 \\
\hline $\mathbf{X}_{\mathbf{H}}$ & 0,52 \\
\hline $\mathbf{X}_{\mathrm{WHITE}}$ & 0,67 \\
\hline $\mathbf{X}_{\mathrm{BPG}}$ & 0,43 \\
\hline $\mathbf{X}_{\mathbf{G}}$ & 0,35 \\
\hline $\mathbf{X}_{\mathrm{ARCH}}$ & 0,51 \\
\hline
\end{tabular}


İkinci modelde de sabitsiz ve trendsiz olarak tahmin edilen uzun dönem ARDL model tahmin sonuçları Tablo 15'de görülmektedir. Tablodaki sonuçlara göre bağımsız değişken bağımlı değişkenle uzun dönemde \%1 anlamlılık düzeyinde pozitif yönlü etkileşim içindedir. Diğer bir ifadeyle KiT katma değerdeki \%1'lik artış, tarım sektörü büyüme hızını \%0,37 artırmaktadır. Modelin güvenilirlik test sonuçlarında göre de değişen varyans ve otokorelasyon sorunu yoktur ve normallik varsayımı açısından da problem bulunmamaktadır.

Tablo 16. İkinci Model Kısa Dönem ARDL Hata Düzeltme Modeli Sonuçları

\begin{tabular}{|c|c|c|}
\hline Değişkenler (Bağımlı Değişken Sanayıb) & Katsayılar & t-istatistiği \\
\hline$D(K D)$ & $-0,088356$ & $-1,951402$ \\
\hline$D(K D(-1))$ & $-0,245229$ & $-2,678278$ \\
\hline$D(K D(-2))$ & $-0,190506$ & $-2,700493$ \\
\hline$D(K D(-3))$ & $-0,095975$ & $-1,570579$ \\
\hline CointEq(-1) & $-\mathbf{0 , 7 4 0 3 7 4}$ & $-3,797646 *$ \\
\hline
\end{tabular}

Tablo 16 'da ikinci model için ARDL hata düzeltme modeli kısa dönem sonuçları görülmektedir. İstatistiksel olarak negatif olması beklenen hata düzeltme modeli bu çalışmada da \%1 önem düzeyinde istatistiksel olarak anlamlı ve negatif işaretlidir. Kısa dönemdeki dengesizlik uzun dönemde ortadan kalkmaktadır.

Şekil 2. İkinci Model CUSUM ve CUSUMSQ Testleri
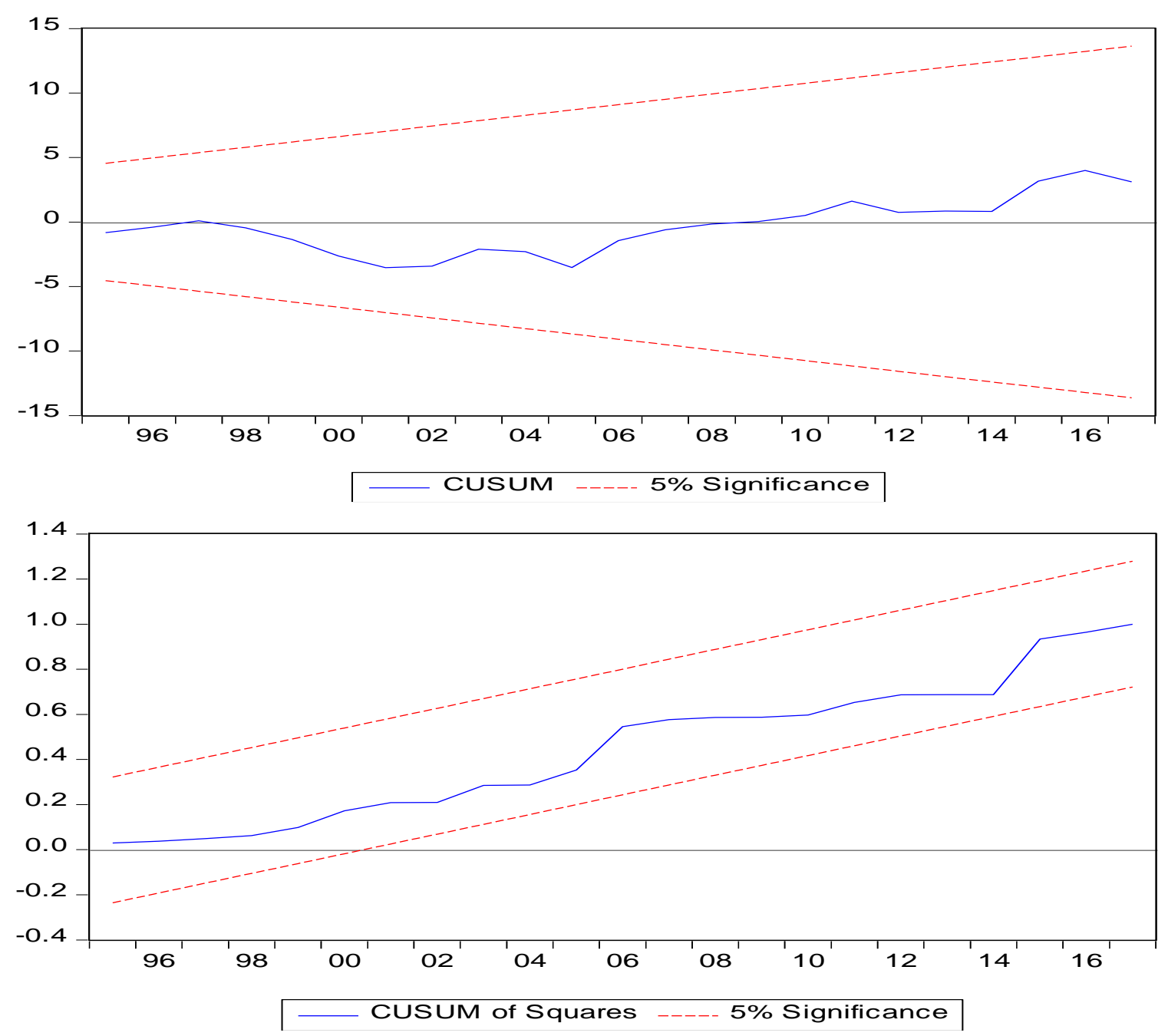
Şekilde görüldüğü üzere dağılım sınırlar içinde kaldığından model istikrarlıdır. Parametreler kararlıdır ve yapısal değişme yoktur.

\section{Toda- Yamomoto Nedensellik Analizi}

Modelde $d_{\max }$ yani maksimum bütünleşme derecesi 0 ve gecikme uzunluğu yani $k=10$ olarak alınmıştır.

Tablo 17. İkinci Model TYT Sonuçları ve Nedensellik Durumu

\begin{tabular}{|l|c|}
\hline Hipotezler (Boş) & Kikare Değerleri \\
\hline KD, TARIMB'nin Granger Nedeni Değildir & $16,36520^{* *}$ \\
\hline TARIMB, KD'nın Granger Nedeni Değildir & $28,51888^{* *}$ \\
\hline
\end{tabular}

Tablo 17 değerleri incelendiğinde ikinci model için de tüm boş hipotezlerin reddedildiği dolayısıyla nedensellik ağının kurulduğu görülmektedir. KiT katma değeri \%5 anlamlılık düzeyinde tarım sektörü büyüme hızı üzerinde nedensellik ilişkisine sahiptir. Değişkenler arasında karşılıklı nedensellik saptanmıştır.

\section{Sonuç}

Yeni kamu işletmeciliği, geleneksel kamu yönetiminin özellikle 1970 'li yıllarda yaşanan ve küresel düzeyde ülkeleri etkileyen petrol krizleri ile birlikte önem kazanmıştır. Ülkeler kamu yönetimi reformlarına giderek, kamuya yönelik kullanılan hantal ve bürokrasinin ağılıkta olduğu yaklaşımdan uzaklaşmışlardır. Türkiye özelinde değerlendirme yapılacak olursa, kalkınma planlarındaki politikaların incelenmesi bu doğrultuda devletin yeni kamu işletmeciliğine bakışını ortaya çıkarmaktadır. Onuncu ve On Birinci Kalkınma Planları eşanlı olarak değerlendirildiğinde her iki planın da kamu işletmeciliğine yönelik benzer hedef ve politikaları devam ettirdiği görülmektedir. 1980 sonrası benimsenen neoliberal politikalarla birlikte gündeme gelen ve 2000 sonrası dönemde hız kazanan özelleştirmelere devam edileceği her iki kalkınma planında da ifade edilmektedir.

Yerel yönetimlerin öz gelirlerinin artırılması her iki kalkınma planında yer alan amaçlardan biri olarak belirtilebilir. Bu amaç yerel yönetimlere ilave gelir kaynağı tahsis edilerek, mali özerkliğin artırıması anlamına gelmektedir. Dolayısıyla yerelleşmeye işaret eden bu amaç, yeni kamu işletmeciliğine yönelik bir başka unsura vurgu yapmaktadır. Nitekim yeni kamu işletmeciliği bağlamında yerelleşme önem taşımaktadır. Ancak bu amacın kalkınma planında yer alıyor olması yerelleşmenin gerçekleştirildiği anlamına gelmemektedir. Bu durum politika tasarımı aşamasında neoliberal unsurların ağıllıkta olduğunu ortaya koymaktadır.

Her iki kalkınma planında da yer alan hedef ve politikaların neoliberal ideolojiyi yansıttığını söylemek mümkündür. Geleneksel kamu yönetimi veya yeni kamu işletmeciliği yaklaşımının benimsenmesi ve politikaların bu doğrultuda hazırlanması, bir ülkenin kamu yönetimine ilişkin yorum yapılabilmesinde tek bir ölçüt olarak kullanılmamalıdır. Üzerinde durulması gereken temel husus her ülkenin kendi iç dinamiklerine, ekonomik, mali ve toplumsal yapısına uygun özellikte politikalar tasarlaması gerektiğidir. Dolayısıyla tek bir yaklaşımın benimsenmesinden ziyade, sektöre, zamana ve bölgelere göre değişen farklı uygulamalar söz konusu olabilir. Her iki yaklaşımın da odak noktası toplumsal refahın artırılması olduğu takdirde, uygulama açısından herhangi bir problemle karşılaşılması olası değildir.

Türkiye'de kamu işletmeciliği kalkınma planları çerçevesinde değerlendirildikten sonra çalışmanın son bölümünde ampirik uygulamaya yer verilmiştir. Bu doğrultuda kamu iktisadi teşebbüsleri tarafından yaratılan katma değerin, tarım ve sanayi sektörü büyüme hızları ile uzun dönemli ilişki ve nedensellik ilişkisi sınanmıştır. Uygulama sonuçları birlikte değerlendirildiğinde; işletmeci Kiт katma değerlerindeki değişim ile alt sektörler olan tarım ve sanayi sektörlerindeki büyüme hızları arasında uzun dönemli bir ilişkinin (eşbütünleşme) varlığı tespit edilmiştir. Katma değerin etkisi her iki alt sektör için pozitiftir. Modeller istikrarlıdır. İstatistiksek olarak sınamayı olumsuz etkileyebilecek unsurlar bulunmamaktadır. Modelde ele alınan yıl aralığı çerçevesinde kırılma dönemleri dikkate alınmıştır. Sonuç olarak söz konusu değişkenler 
arasında uzun dönemli pozitif ilişki olduğu tespit edilmiştir. Kamu iktisadi teşebbüslerinin katma değerlerinin artışı hem tarım hem de sanayi sektöründeki büyüme hızlarına artış yönlü etki yapmaktadır. Kiт’lerin etkin ve verimli bir şekilde faaliyetlerinin sürdürüldüğü takdirde sektörlere katkı sağladığı buradan hareketle ifade edilebilir. Dolayısıyla kalkınma planlarında yer alan KiT'lerin tam kapasitede, etkin olarak sürdürülmesi politikası bu açıdan değerlendirildiğinde işlevseldir. Buradan hareketle diğer unsurlar değişmez kabul edildiğinde KiT işletme mantığı ve nosyonu çerçevesinde kaynak kullanımı ve etkinliği, planlama, kamusal fayda anlayışı ve rekabet ortamı sağlama gibi unsurlar çerçevesinde KiT'lerden beklenen fonksiyonların yerine geldiği ifade edilebilir.

\section{Beyan ve Açıklamalar (Disclosure Statements)}

1. Bu çalışmanın yazarları, araştırma ve yayın etiği ilkelerine uyduklarını kabul etmektedirler (The authors of this article confirm that their work complies with the principles of research and publication ethics).

2. Yazarlar tarafından herhangi bir çıkar çatışması beyan edilmemiştir (No potential conflict of interest was reported by the authors).

3. Bu çalışma, intihal tarama programı kullanılarak intihal taramasından geçirilmiştir (This article was screened for potential plagiarism using a plagiarism screening program).

\section{Kaynaklar}

Akbulut, Ö. (2007). Kamu yönetiminde işletmecilik sorunu. Mülkiye Dergisi, 31(254), 73-86.

Aktan, C. C., \& Bahçe, A. B. (2013). Kamu Tercihi perspektifinden oyun teorisi. Hukuk ve iktisat Araştırmaları Dergisi, 5(2), 93-117.

Alkan, B. Ş. (2018). Yeni kamu işletmeciliği yaklaşımından hareketle kamu idarelerinde mali analiz uygulaması. Uluslararası iktisadi ve Idari Incelemeler Dergisi, 17(UiK Özel Sayısı), 799-812.

Altıntaş, H. (2013). Türkiye'de petrol fiyatları, ihracat ve reel döviz kuru ilişkisi: ARDL sınır testi yaklaşımı ve dinamik nedensellik analizi. Uluslararası Yönetim iktisat ve işletme Dergisi, 9(19), 1-30.

Araujo, J. F. F. E., \& Branco, J. F. A. (2009). Implementing performance-based management in the traditional bureaucracy. Public Administration, 87(3), 557-573.

Ayhan, E., \& Önder, M. (2017). Yeni kamu hizmeti yaklaşımı: Yönetişime açılan bir kapı. Gazi iktisat ve işletme Dergisi, $3(2), 19-48$.

Çetinkaya, Ö. (2012). Türkiye'de Kamu işletmeciliği ve özelleştirme (3.Baskı). Bursa: Ekin Basım Yayın Dağııım.

Dura, Y. C. (2006). Kamu tercihi teorisinde kamusal etkinlik problemi. Türk Idare Dergisi, (451), 107-117.

Engle, R., \& Granger, C. W. J. (1987). Cointegration and error-correction: Representation, estimation and testing. Econometrica, 55(2), 251-276.

Genç, F. N. (2010). Yeni Kamu hizmeti yaklaşımı. Türk Idare Dergisi, (466), 145-160.

Güler, H. (2019). Türkiye'de mali kriz sonrası kurallı maliye politikasının bir aracı olarak özelleştirme politikaları. Siyaset, Ekonomi ve Yönetim Araştırmaları Dergisi, 7(1), 77-92.

Güzelsarı, S. (2004). Kamu Yönetimi disiplininde yeni kamu işletmeciliği ve yönetim yaklaşımları. Ankara Üniversitesi Siyasal Bilgiler Fakültesi GETA Tartışma Metinleri Serisi, Ankara.

Hazine ve Maliye Bakanlığı (2019). 2018 Kamu işletmeleri Raporu. https://ms.hmb.gov.tr/uploads/2019/10/2018_Kapak_Kamu_isletmeleri_apor_we.pd (Erişim Tarihi: 25.01.2020).

Hughes, O. E. (2014). Kamu Iş̧letmeciliği \& yönetimi (Çev. Buğra Kalkan, Bahadır Akın, Şeyma ～Akın). Ankara: BigBang Yayınları.

Johansen, S. (1988). Statistical Analysis of cointegrating vectors. Journal of Economic Dynamics and Control, 12(2-3), 231-254.

Johansen, S., \& Juselius, K. (1990). Maximum likelihood estimation and inferance on cointegration with applications to the demand for money. Oxford Bulletin of Economics and Statistics, 52(2), 169-210. 
Işıkçı, Y. M. (2017). Yeni kamu işletmeciliği perspektifinden çocuk koruma hizmetlerinin yeniden yapılandırılması. Akademik Yaklaşımlar Dergisi, 8(1 ilkbahar), 40-64.

Kabasakal, A., \& Solak, A. O. (2008). Evrensel Hizmet yükümlülüğünün uygulanması ve Türk demiryolu sektörü. Bilgi Ekonomisi ve Yönetimi Dergisi, 3(2), 137-146.

Kamacı, A., \& Kara, S. Ş. (2019). Üçüz açık hipotezi: 1974-2015 yılları arası türkiye örneği. Uluslararası Afro-Avrasya Araştırmaları Dergisi, 4(8), 143-154.

Karayılmazlar, E., \& Özgün, M. (2019). Tasarruflar ile dış borçlar arasındaki ilişkinin ampirik analizi: Türkiye örneği. Hacettepe Üniversitesi Iktisadi ve Idari Bilimler Fakültesi Dergisi, 37(3), 489-516.

Karcı, Ş. M. (2008). Yeni kamu işletmeciliği yaklaşımının temel değerleri üzerine bir inceleme. Akdeniz Üniversitesi I.i.B.F. Dergisi, (16), 40-64.

Kaya, F. (2017). Kamu yönetimi yaklaşımlarının karşılaştırmalı analizi. Uluslararası Sosyal Araştırmalar Dergisi, 10(53), 747-755.

Kıran, B., \& Güriş, B. (2011). Türkiye'de ticari ve finansal dışa açıklığın büyümeye etkisi: 1992-2006 dönemi üzerine bir inceleme. Anadolu Üniversitesi Sosyal Bilimler Dergisi, 11(2), 69-80.

Kurt, A. (2018). Türkiye'de özelleştirme politikalarının ekonomik boyutu ve işçi sendikalarının özelleştirmeye yaklaşımları: 1980-2015 dönemi. Marmara Üniversitesi Sosyal Bilimler Enstitüsü, Doktora Tezi, İstanbul.

Kurun, í. (2017). Yeni Kamu işletmeciliği yaklaşımının kamu hizmetlerine etkisi : Belediyeler örneği. Bartın Üniversitesi i.i.B.F. Dergisi, 8(16), 85-106.

Leblebici, D. N. (2001). Disiplin ve uygulama açısından kamu yönetiminin "kimlik krizine” yeni bir bakış. Cumhuriyet Üniversitesi Sosyal Bilimler Dergisi, 25(1), 15-24.

Lynn Jr, L. E. (2001). The myth of the bureaucratic paradigm: What traditional public administration really stood for. Public Administration Review, 61(2), 144-160.

Narayan, P. K. (2005). The saving and investment nexus for China: Evidence from cointegration tests. Applied Economics, 37(17), 1979- 1990.

Newman, J. (2000). Beyond the new public management? Modernizing public services. İçinde J. Clarke, S. Gewirtz, \& E. McLaughlin (Ed.), New managerialism, new welfare (ss. 45-61). Sage London.

Olsen, J. P. (2006). Maybe it is time to rediscover bureaucracy. Journal of Public Administration Research and Theory, 16(1), 1-24.

Övgün, B. (2009). Türkiye'de kamu iktisadi teşebbüsü olgusu. http://mulkiye.org.tr/wpcontent/uploads/2015/09/41.pdf (Erişim Tarihi: 15.11.2019).

Pesaran, H., Shin, Y., \& Smith, R. J. (2001). Bounds testing approaches to the analysis of level relationships. Journal of Applied Econometrics, 16, 289-326.

Polidano, C. (1999). Public management reform in developing countries. Working Paper No 13.

Sarısu, A. (2008). Hükümetlerimiz ve özelleştirme uygulamaları. Yaklaşım Dergisi, (190), 213-220.

Şener, H. E. (2007). Kamu yönetiminde postmodernizm. İçinde Ş. Aksoy \& Y. Üstüner (Ed.), Kamu yönetimi: Yöntem ve sorunlar (ss. 31-47). Ankara: Nobel.

Sobacı, M. Z. (2006). Türkiye'de kamu yönetimi reformlarının "yeni kamu işletmeciliği" perspektifinden bir degerlendirmesi. Akademik Araştırmalar Dergisi, (28), 71-86.

Soeters, J. L., \& Tessema, M. T. (2004). Public management in developing countries: Some notes on Eritrea. International Review of Administrative Sciences, 70(4), 623-635.

Stiglitz, J. E. (1998). An agenda for development in the twenty-first century. Annual World Bank Conference on Development Economics 1997, 17-31. World Bank Washington DC.

Tuncer, A., \& Usta, S. (2013). İki kriz arasında yönetim : Yeni kamu işletmeciliği. Selçuk Üniversitesi Sosyal Bilimler Enstitüsü Dergisi, (30), 181-195.

T.C. Cumhurbaşkanlığı Strateji ve Bütçe Başkanlığı, T. (2019). On Birinci Kalkınma Planı (2019-2023). http://www.sbb.gov.tr/wp-content/uploads/2019/07/OnbirinciKalkinmaPlani.pdf (Erişim Tarihi: 20.11.2019).

T.C. Kalkınma Bakanlığı. (2013). Onuncu Kalkınma Planı (2014-2018). http://www.sbb.gov.tr/wpcontent/uploads/2018/11/Onuncu-Kalkınma-Planı-2014-2018.pdf (Erişim Tarihi: 25.11.2019).

Yamaçli, D. S., \& Saatçi, M. (2016). Türkiye'de tüketici enflasyonunun iktisadi belirleyicileri: ARDL Analizi. Business and Economics Research Journal, 7(3), 53-71. 
Yavuz, N. Ç. (2006). Türkiye'de turizm gelirlerinin ekonomik büyümeye etkisinin testi: Yapısal kırılma ve nedensellik analizi. Doğuş Üniversitesi Dergisi, 7(2), 162-171.

Yıldırım, M. (2009). Modernizm, postmodernizm ve kamu yönetimi. Uluslararası Insan Bilimleri Dergisi, 6(2), $380-397$.

Yıldırım, M. (2011). Pragmatizm ve yeni kamu işletmeciliği. H. Ü. Iktisadi ve Idari Bilimler Fakültesi Dergisi, 29(1), 187208. 
This Page Intentionally Left Blank 